\title{
درجة ممارسة القيادات الأكاديمية في جامعة عدن للاقيادة الأخلاقية وعلاقتها بالولاء التشيمي
}

\author{
علي محمد قاسم عبيد القحطاني1،*، نوال جواد سالم محمد حميدي 1 \\ 1 قسم الأصول والإدارة التربوية، كلبة التربية ـ عدن، جامعة عدن، البين
}

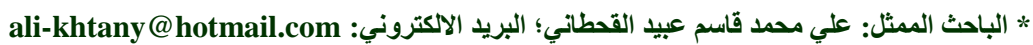

استلم في: 02 سبتمبر 2021 / قبل في: 02 أكتوبر 2021 / نشر في: 31 ديسمبر 2021

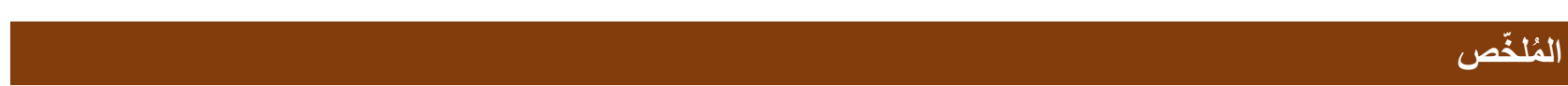

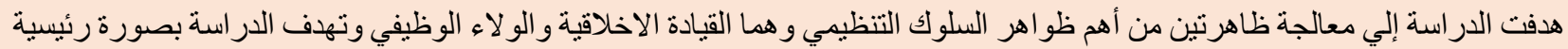

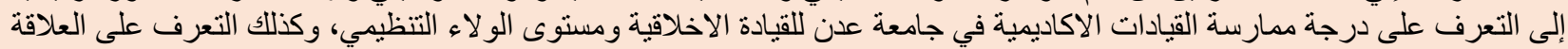

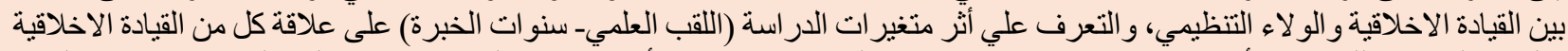

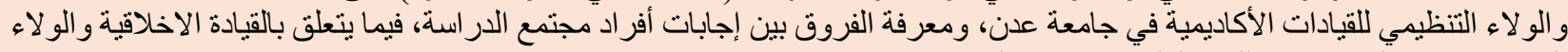

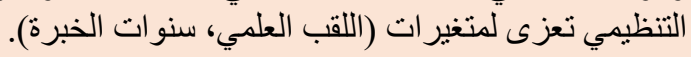
ولتحقيق هدف الدر اسة تم إعداد الاستبانة وتحتوي على (50) فقرة موزعة على على محوريين (الصفات الاخلاقية والو لاء الاء التنظيمي) بعد عرضها

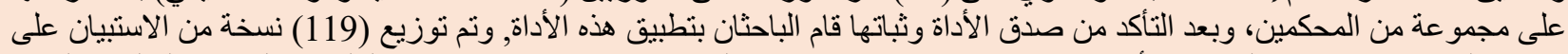

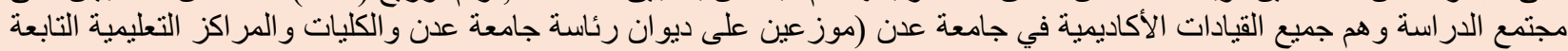

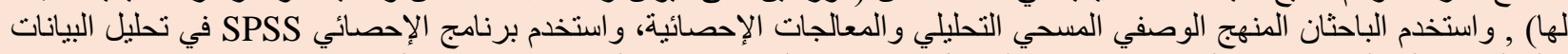

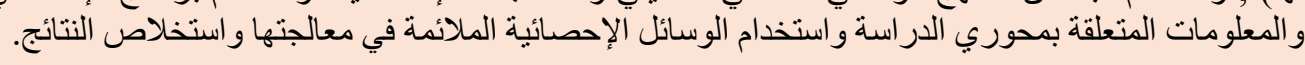

أظهرت الدر اسة مجمو عة من النتائج أهمها:

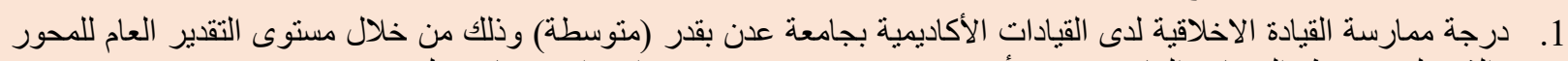

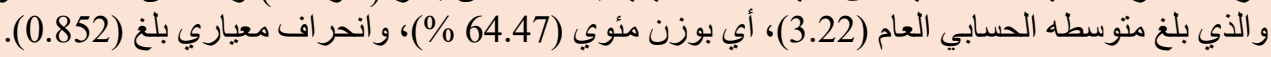

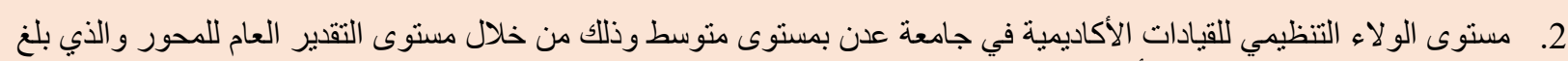

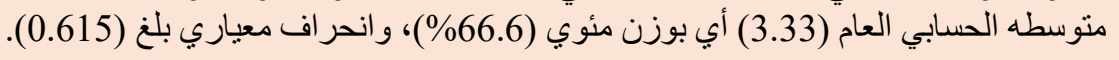

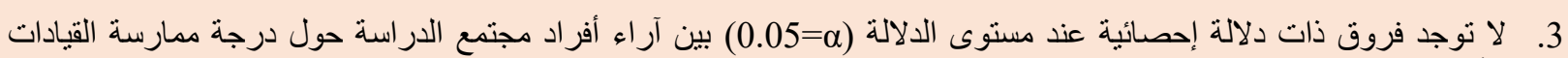

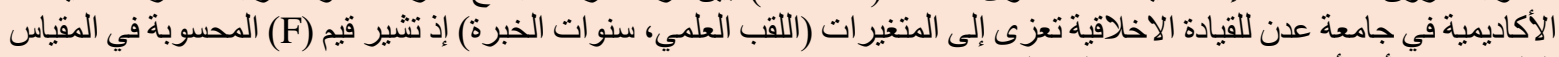

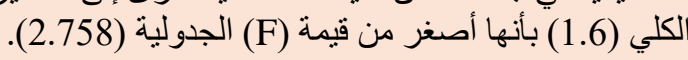

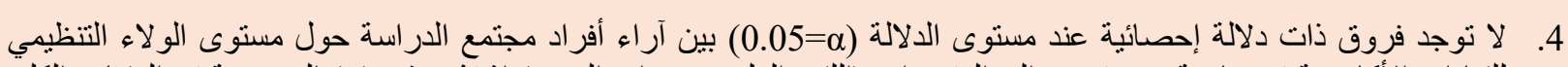

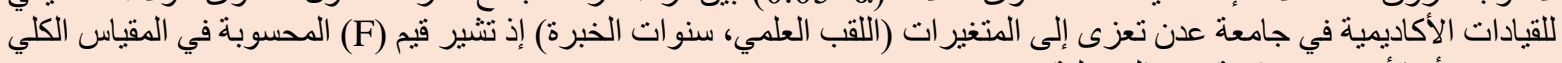

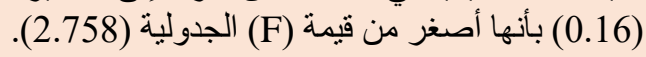

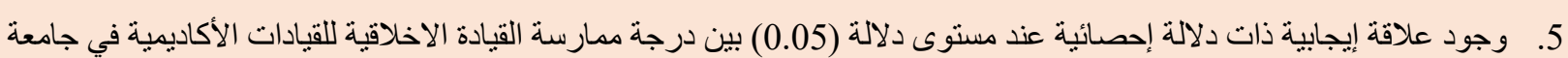
عدن وبين مستوى و لائهم التنظيمي.

أن الأمم ترنقي من خلال الأخلاقيات التي تسود فيها وتحكمها تصرفات الأفراد و المؤسسات، وحظيت القيادة باهتمام الباحثين و المرتمين الإني

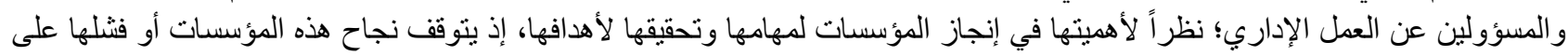

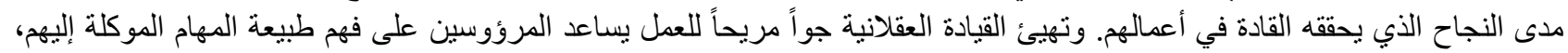

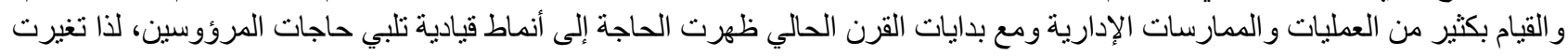

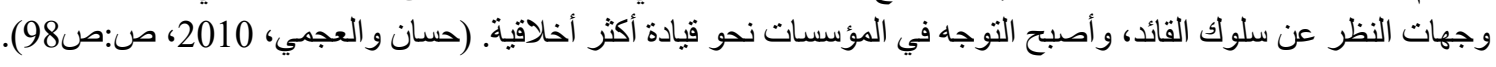

وللقيادة الأخلاقية دوراً كبيراً في توجيه المؤسسات التربوية للاضطلاع بأدو ارهاومسؤولياتها من خلال ما تقدمه من خدمة تساعد العاملين

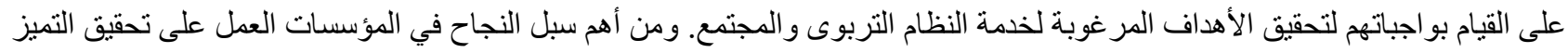

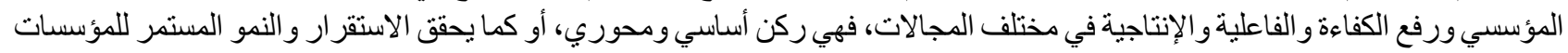


بل يقال بأنها عامل نجاح حر للمجتمعات. فهي عامل مساعدة للقادة لمواجهة التحديات من خلال التأكيد والقيم الأخلاقية داخل بيئة العمل التي

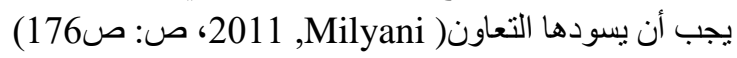

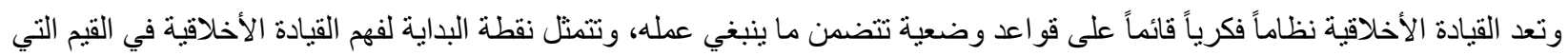

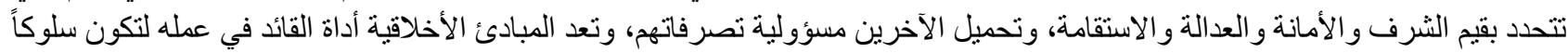

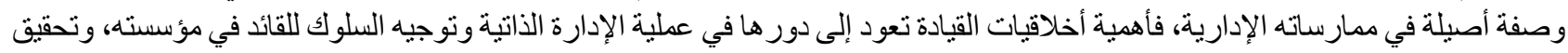

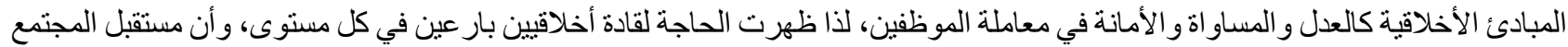

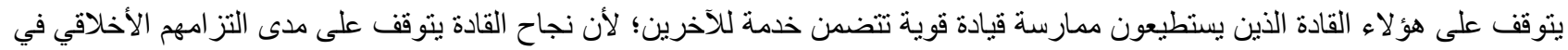

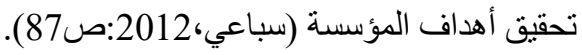

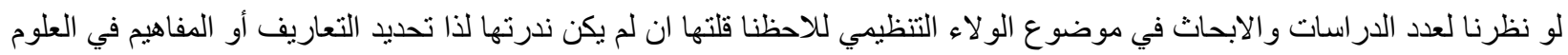

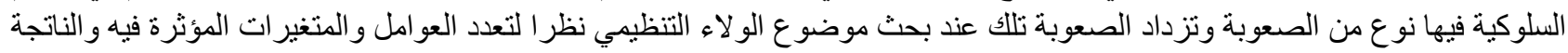

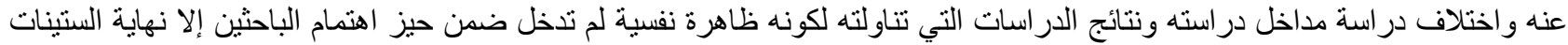
واو ائل السبعينات. (Milyani, 2011، 2ناف صن: 243)

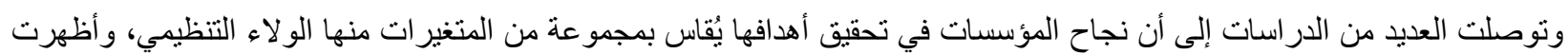

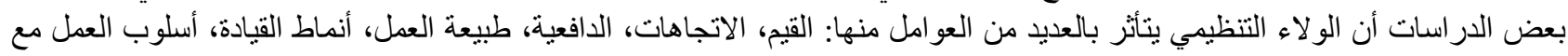

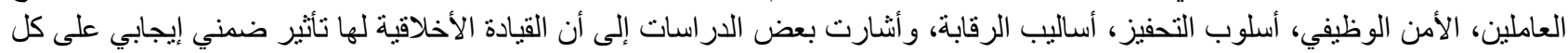

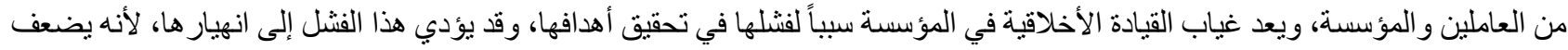

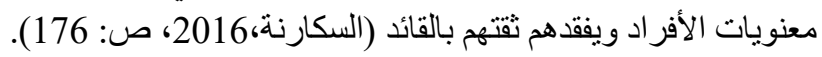

مشكلة الار اسةة:

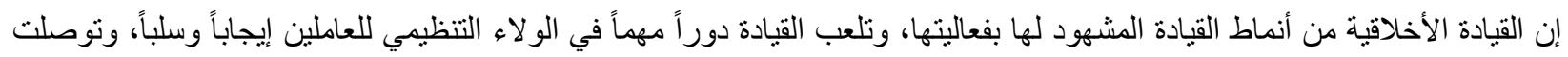

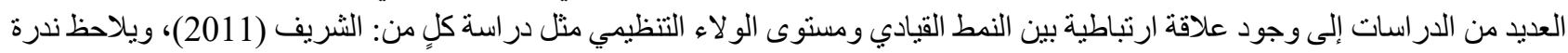

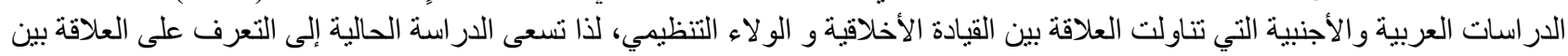

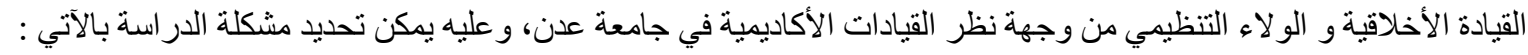

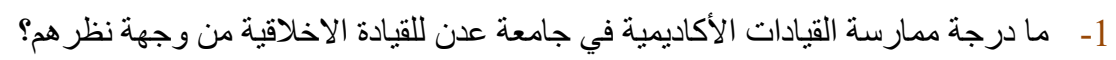

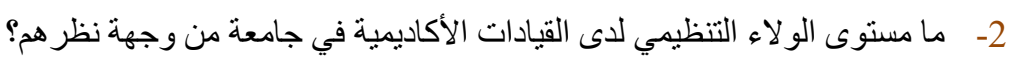

3- هل توجد فروق ذات دلالة إحصائية عند مستوى دلالة (0.05) بين استجابات أفراد مجتمع الدراسة حول ممارسة القيادات الأكاديمية

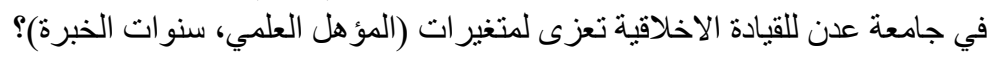

4- هل توجد فروق ذات دلالة إحصائية عند مستوى دلالة (0.05) بين استجابات أفر اد مجتمع الدر اسة حول مستوى الو لاء التنظيمي تعزى لئي لمتغير ات (المؤهل العلمي، سنوات الخبرة)

5- هل توجد علاقة ارتباطية دالة إحصائياً بين القيادة الأخلاقية والو لاء التنظيمي لدى القبادات الأكاديمية في جامعة عدن؟

أهداف الار اسية:

1- التعرف درجة ممارسة القيادات الأكاديمية في جامعة عدن للقيادة الاخلاقية.

2- التعرف على مستوى الو لاء التتظيمي لدى القيادات الأكاديمية في جامعة عدن.

3- الكثف عن الفروق الإحصائية بين استجابات أفر اد مجتمع الدراسة حول درجة ممارسة القيادات الأكاديمية في جامعة عدن للقبادة

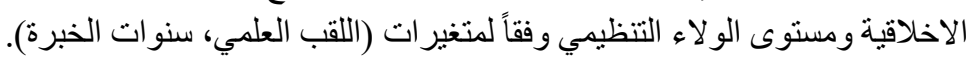

4- تحديد العلاقة بين القيادة الأخلاقية والو لاء التنظيمي لدى القيادات الأكاديمية في جامعة عدن.

أهمبة الدراسة:

تكمن الأهمية الدر اسة في النقاط الآتية: - من أهمية الأخلاق ومستوى تأثير ها على الآخرين. 


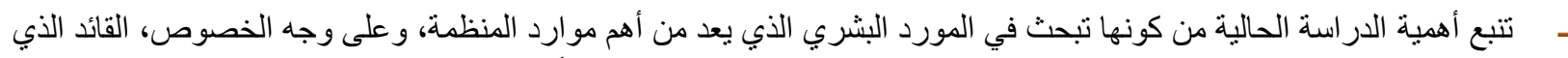

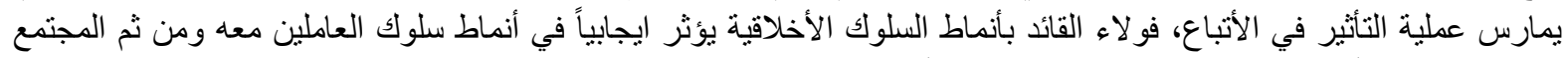

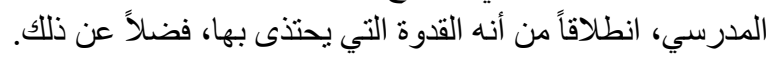

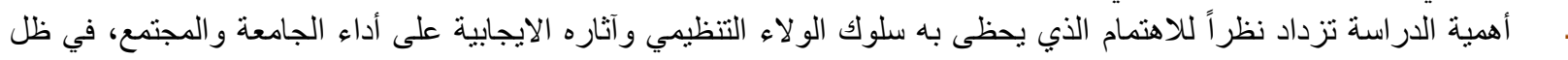

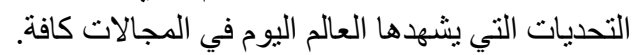

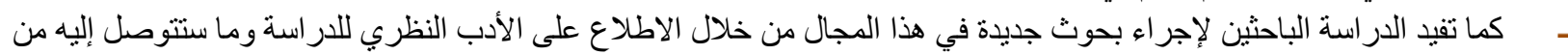

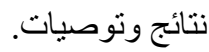

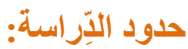

تتضمن حدود الدر اسة طبقاً للنقاط الآتية: 1- حدود موضو عية: وتثمل الدر اسة على: - موضوع القيادة الاخلاقية بمجالاته الآتية: م. الصفات الثخصية الاخلاقية. بـ الصفات الإدارية الاخلاقية. • العلاقات الانسانية. - موضوع الو لاء التنظيمي بمجالاته الآتية:

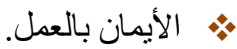

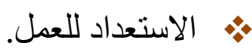

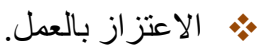
2- 2 - مدود مكانية: جامعة عدن. 3- حدود بشرية: تكونت عينة البحث من (119) من القيادات الأكاديمية بجامعة عدن رئبس الجامعة ونو ابه وعمداء الكليات ونو ابهم ومدر اء المر اكز التعليمية. 4- حدود زمانية: العام الجامعي 2021م. منهبية الدراسة: - ماسة اعتمد الباحثان المنهج الوصفي الارنباطي من خلال التعرف على درجة ممارسة القيادات الأكاديمية بجامعة عدن للقيادة الأخلاقية وعل|قتها بالو لاء التنظيمي.

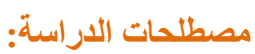

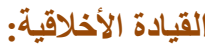
- يعرفها عابدين (2012): "بأنها إظهار سلوك قيادي من حيث الالتزام بالمعايير المعتمدة والمقبولة في التصرفات الثخصية والعلاقات بين

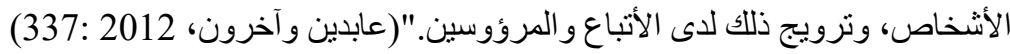
- هي التأثير في العاملين لتحقيق درجة عالية من الكفاءة والفعالية، وإيجاد المناخ التنظيمي المنتج الذي يسوده التعامل ضمن الإطار الأخلاقي،

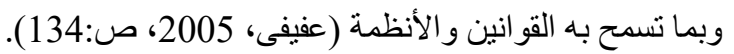

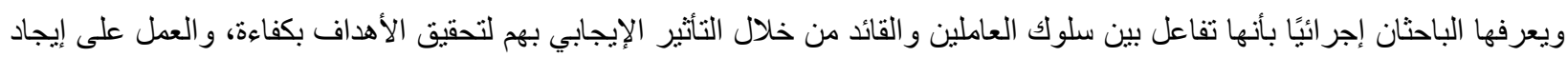
بيئة عمل مناسبة يسودها علاقات إنسانية ضمن إطار أخلاقي تحكمه القو انين والأنظمة و التشريعات. الو لاء التنظيمي:

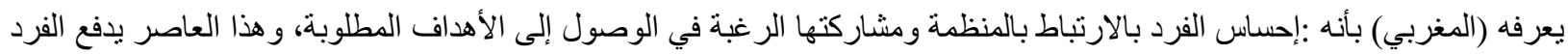

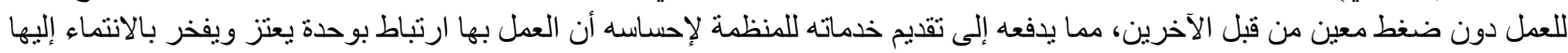
و هنا يصبح تحقيق الأهداف أملاً ورغبة للآنميع لأنه لا بديل في الانضمام للمنظمة. (المغربي،2007: ص25) 


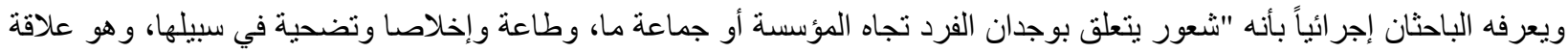

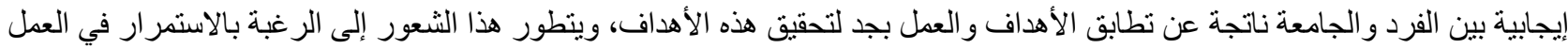

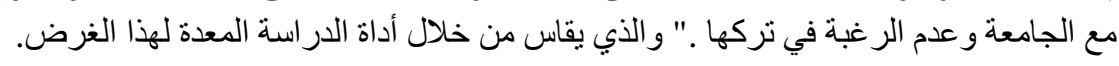

\section{الإطار النظّري

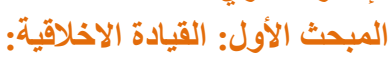

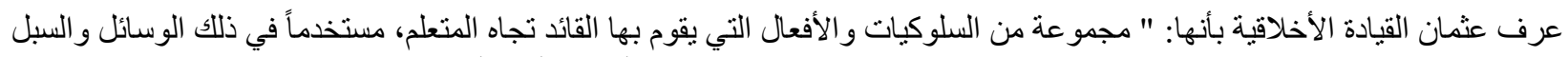

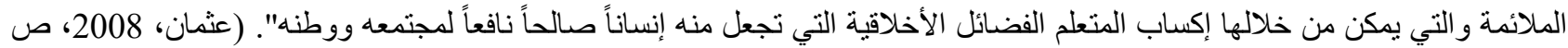

وعرفها الزيناتي بأن القيادة الأخلاقية تنال قدر من الاهتمام في الأنظمة والمؤسسات التربوية، وذللك لأنها تهتم بالكثير من العو امل التي تؤثر

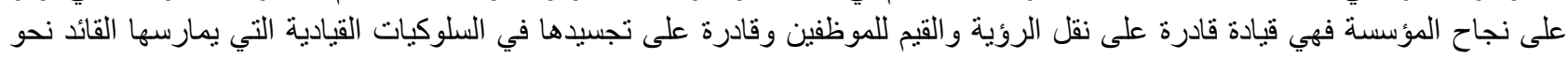

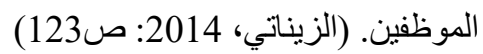

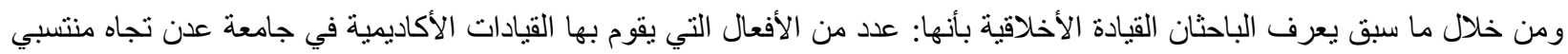

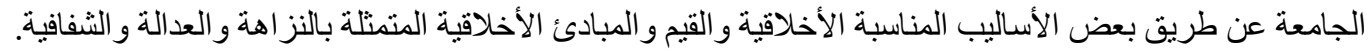

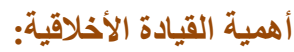

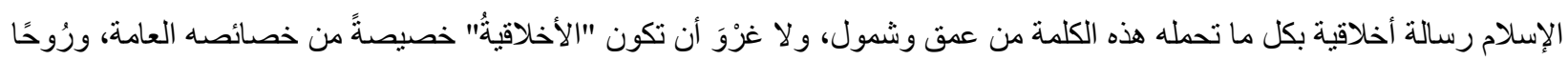

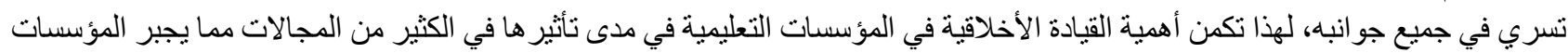

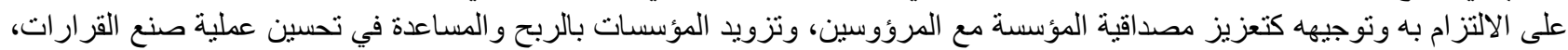

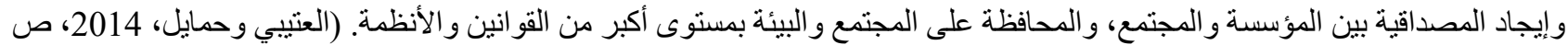

ويشير (عفيفى) إلى أهمية القيادة الأخلاقية لدى الرؤساء والمشرفين في المؤسسات التعليمية حيث إنها تعمل على تعزيز الفهم والإدراك

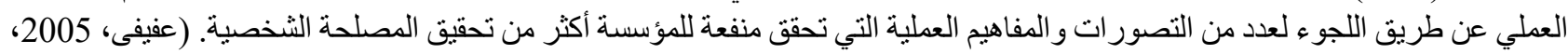

ص:135)

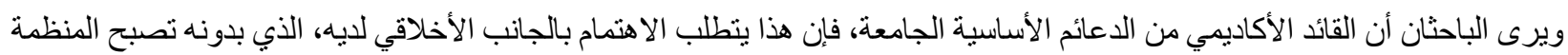

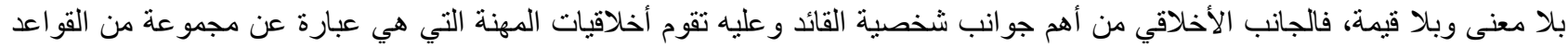

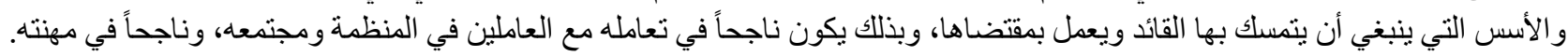

مرتكزات القيادة الأخلاقية:

العلاقات الإنسانة ببن القائد ومرؤوسيه: و هي العلاقة التي تدفع العاملين لإنجاز العمل بشكل تعاوني وتتمحور العلاقات الإنسانية بين القائد

- حصول اندماج بين العاملين و التنظيم الذي يعملون فيه، مما ينعكس على إنجاز العاملين.

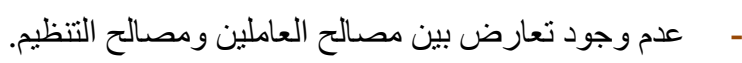
- - مأن يتم التعامل مع العاملين في التظيم بشكل أخلاقي و إنساني يحفظ لهم كر امتهم.

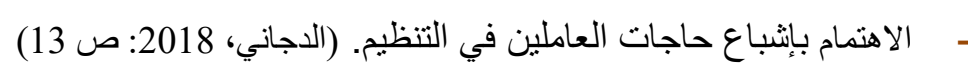

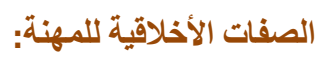
يشير السكارنة، (2016) إلى أنه يمكن حصر الصفات الأخلاقية للمهنة في خمس

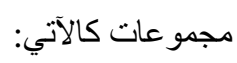
- - الطهارة و القدسية عن طري حسن السيرة و السلوك وجودة الأداء.

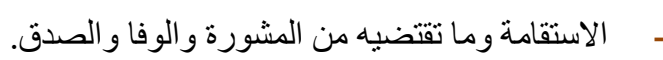
- ـ التعاون وما يستلزمها من تعميق معاني الأخوة و الاحتر ام و الصبر.

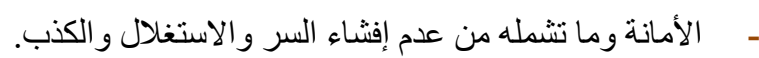


- - المحبة وما تشمله من معاني الواد و الإحسان و الإيثار . (السكارنة، 2016، ص: 131)

مبادئ القبادة الأخلاقية: وتتمثل مبادئ القيادة الأخلاقية بالآتي:

1. النز اهة و الثفافية في العمل: والتي تأتي لتنسجم مع المبادئ الإنسانية السامية لدى القيادة الأخلاقية. 2. المسؤولية: وهي تحمل القادة مسؤولية الأعمال و النتائج المتوقعة لتلك الأعمال والتي تتضمن أن تتوافق مع المبادئ الإنسانية السامية وتشتمل المسؤولية على ما يلي: أ- القدرة على تحمل المسؤولية الثخصية. ب- الاعتر اف بحالات الفنل ومواطن الأخطاء. ج- تحمل المسؤولية لخدمة الآخرين. 3. العدل: فمن الأخلاقيات أن يحرص القائد على العدل ويعمل بروحه ويؤثر على العاملين ليكون أقرب إليهم. 4. الاتزان الانفعالي: و الذي بساعد القائدة على التفاهم مع العاملين في المؤسسة. (العتيبي، 2013، ص 15)

الحاجة للقيادة الأخلاقية:

اصبحت الجامعات بحاجة ماسة إلى قيادات أخلاقية تتمتع بالمهار ات الازمة للقيادة بطرق فعالة للمضي بالجامعات إلى النجاح و التفوق،

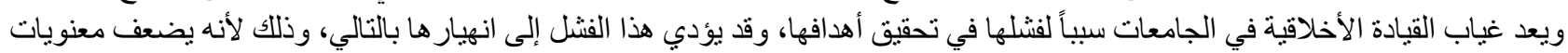

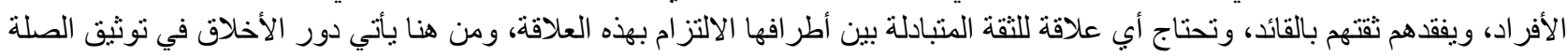

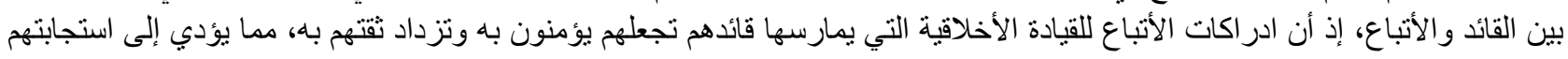

للمسؤولية عن عملهم من منطلق حرصهم الدائم على الالتز ام بعلاقاتهم بالقائد. (Ruiz, 2011, P:590)

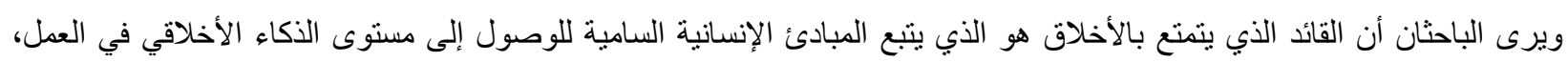

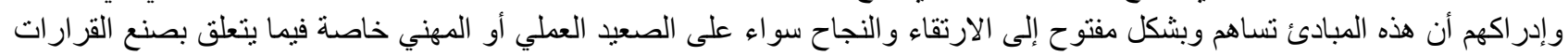

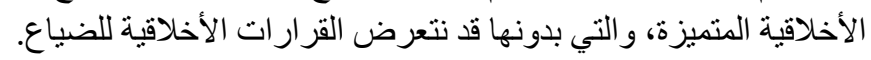

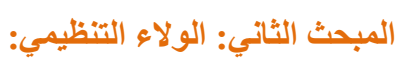
مفهوم الولاء الثنظيمي:

عرفه (العتيبي) على أنه " شعور يتملك الفرد تجاه المنظمة ينتج عنه انسجام مع المنظمة و أهدافها و الرغبة في البقاء فيها و النظرة الايجابية

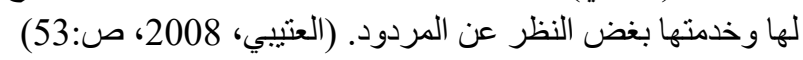

و عرف (أبو النصر ) الو لاء التظيمي هو الإخلاص للمؤسسة يعني مشاعر ذلك الفرد نحو المؤسسة التي يعمل بها، واتجاهاته وترتبط هذه

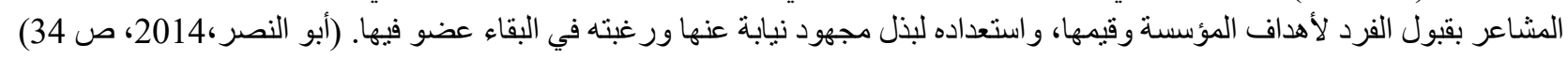
و عرفه الباحثان إجر ائياً بأنه "شعور يتعلق بوجدان الفرد تجاه المؤسسة أو جماعة ما، وطاعة وإخلاصا وتضحية في سبيلها، وهو علاقة

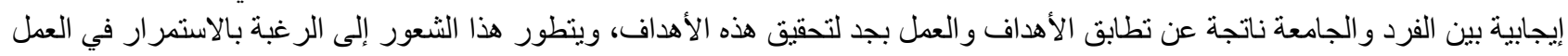

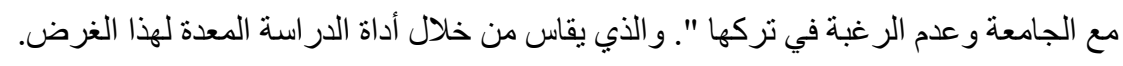
أهمية الولاء التنظليمي:

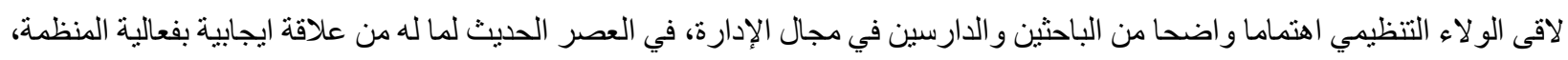

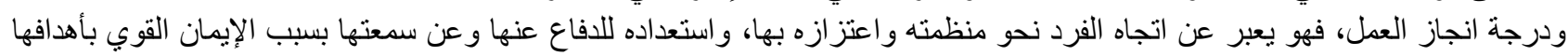

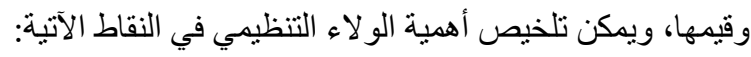

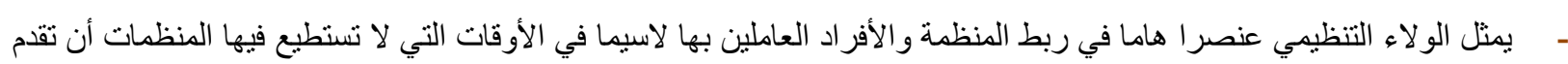
الحوافز الملائمة لدفع هؤ لاء الأفر اد العاملين للعمل، وتحقيق ربط أعلى مستوى من الانجاز. إن و لاء الأفر اد لمنظمـتهم التـي يعملـون بهـا يعتبـر عـاملا هامـا أكثر مـن الرضـا الـوظيفي في التنبؤ في بقائهم في منظمـاتهم

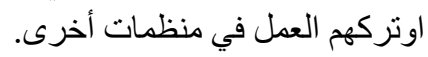

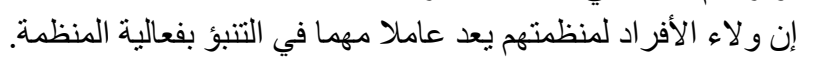
- إن الو لاء التنظيمي من أكثر المسائل التي أخذت بال إدارة المنظمات. 


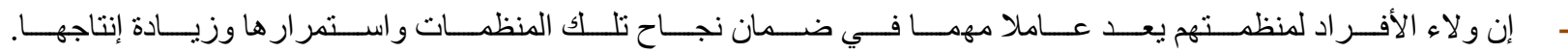

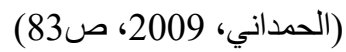

ويرى الباحثان ان الو لاء التظظيمي يعتبر عاملا هاما، فمن خلاله تضمن المنظمة نجاحها وقيامها وزيادة إنتاجها، وكذلك من خلاله تستطيع

التنبؤ ببقاء العمال في المنظمة أو الون تركها.

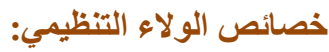

يتميز الو لاء التنظيمي بعدد من الخصائص تتمثل في:

- - إن الو لاء التنظيمي حصيلة تفاعل العديد من العوامل الإنسانية و التنظيمية وظو اهر إدارية أخرى داخل التنظيج.

- إن الو لاء التنظيمي لن يصل إلى مستوى الثبات المطلق إلا أن درجة التغير التي تحصل فيه تكون اقل نسبيا من درجة التغير التي تتصل

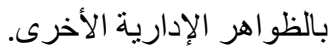

ـ إن الولاء التنظيمي حالة غير ملموسة يستدل عليها من الظو اهر التنظيمية تتابع من خلال سلوك وتصرفات الأفراد العاملين في التنظيم

و التي تجسد مدى و لائهم.

- أن الو لاء التتظيمي متعدد الأبعاد وليس بعدا واحد، ورغ وغم اتفاق غالبية الباحثين في هذا المجال عل تعدد أبعاد الو لاء إلا أنهم يختلفون في

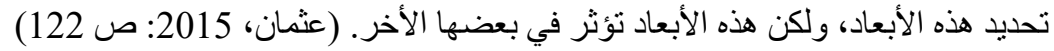

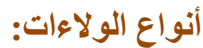

هناك عدة أنواع من الو لاءات لاى الفرد يمكن ذكر أبرز ها كما يلي:

1) الولاء المؤسسي أو التنظيمي: وهو و لاء العامل للمنظمة أو المؤسسة التي يعمل بهاو هو موضوع الدراسة الحالية الذي سنتطرق إليه

بالتفصيل.

2) الو لاء الوطني: وهو و لاءك للوطن الذي تتتمي إليه، فكل واحد منا موطن في بلد ما، وله جنسية هذا البلد، ويزداد و لاءك الوطني كلما

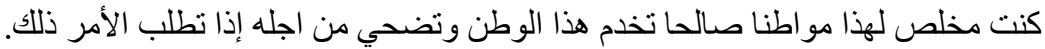

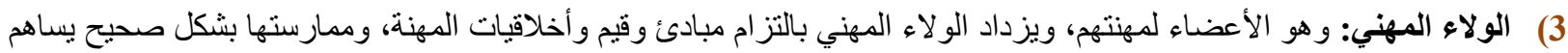

في تحقيق أهداف هذه المهنة.

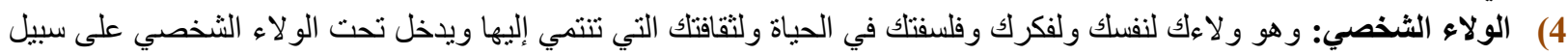

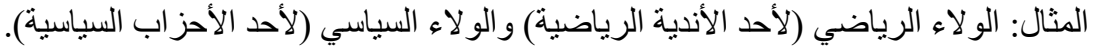

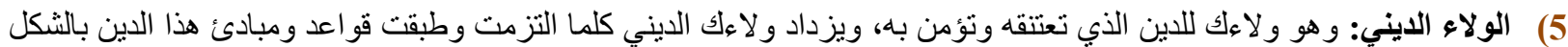

الصحيح.

6) الولاء للعملاء: و هو الو لاء الجمهوري للمنظمة والعملاء هم الذين تقدم لهم السلع أو الخدمات. (أبو النصر،2014، ص:47)

مقومات الولاء التنظيمي:

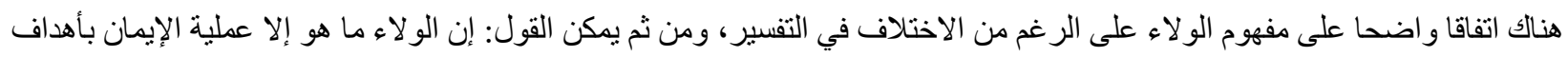

المنظمة وقيمها و العمل بأقصى طاقة ممكنة لتحقيق تلك الأهداف وتجسيد القيم وبهذا يمكن بالقول: إن للو لاء التنظيمي مقومات التهات أساسية منها:

- مبول أهداف المنظمة وقيمها.

- بذل مستوى عال من الجهد لتحقيق أهداف التنظيم.

- أن يكون على درجة عالية من الإنغماس الثديد في التنظيم والو لاء له.

- م - الرغبة الثديدة في البقاء في التنظيم فترة طويلة.

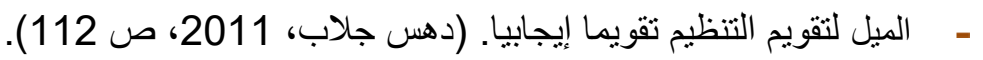

العو امل المساعدة في تكوين الو لاء التنظيمي:

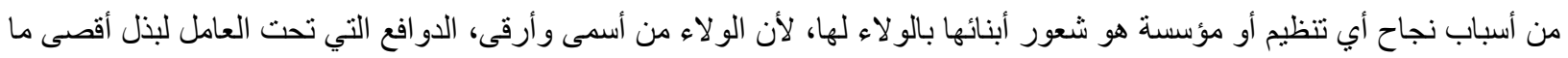

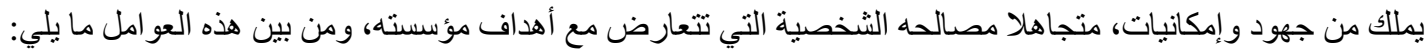

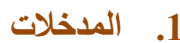

تشير معظم الدراسات التي أجريت في مجال الو لاء التنظيمي أن من أهم العوامل التي تساهم في تتمية ولاء العاملين لتنظيماتهم هي: 


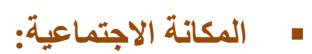

يقصد بالمكانة" تلك المرتبة الاجتماعية للشخص مقارنة بآخرين في أي نظام اجتماعي." وقد تكون المكانة مكانة رسمية أو مرتبة اجنماعية

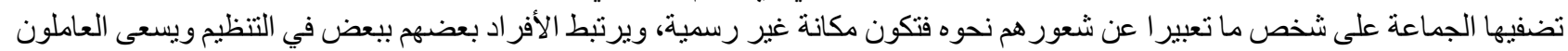
ببذل قصارى جهودهم للمحافظة عل مكانتهم.

$$
\text { - قيام المؤسسة بمساعدة القرد على إثباع حاجاته: }
$$

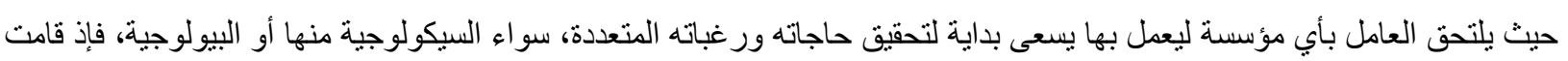

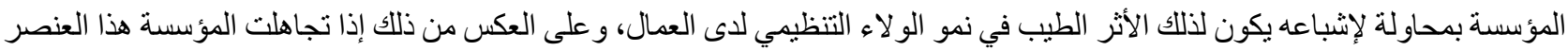

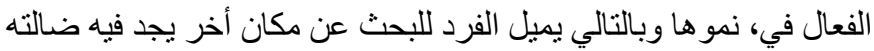

$$
\text { : - تطام الحواقز: - }
$$

للحو افز دور فاعل في تعزيز العلاقات فيما بين التنظيم و العاملين فيه، فهي التي تحفز القوى الدافعة بغيةتحقيق أهداف التنظيم، وهذه الحوافز

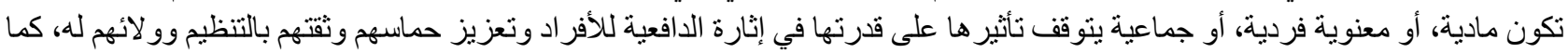

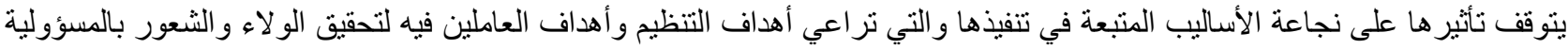
والشعور بالرضا وتحقيق الذات. يتضح أن للحوافز المادية أو المعنوية دور في تنمية الولاء التنظيمي، لدى الأفراد فهي تعزز العلاقات بين المنظمة والأفر اد مما يدفعهم

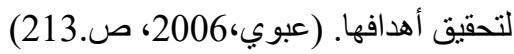
- ب بناء الثقة التنظيمية:

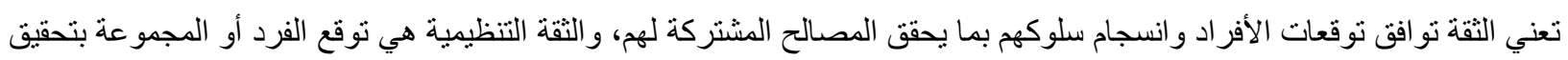

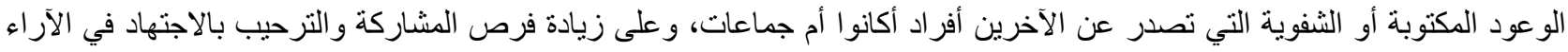

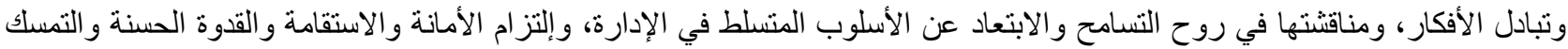

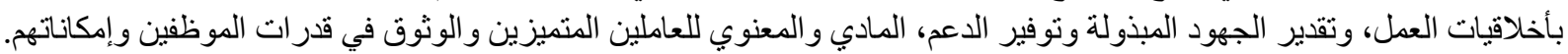

$$
\text { - التبطيع التنظيمي: }
$$

نعني بالتطبيع الاجتماعي التنظيمي"العمليات التي يكتسب فيها الفرد القيم الاتجاهات و المعاير و أنماط السلوك التي تتو افق مع مصالح المنظمة

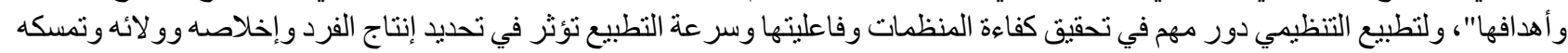
بالمنظمة، فهو بذللك يحقق بعد من أبعاد الو لاء التنظيمي إلا و هي بذل أقصى جهد من اجل إنجاح وتحقيق أهداف هذه المنظمة وقيمتها والتوجه نحو الانجاز المبدع.

$$
\text { : . : مضوح الأهداف: }
$$

يساعد وضوح الأهداف التنظيمية على زيادة الو لاء التنظيمي لدى الافر اد العاملين، فكلما كانت الأهداف واضحة ومحددة وكلما كانت عملية

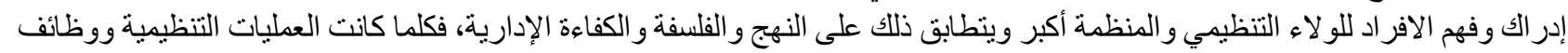

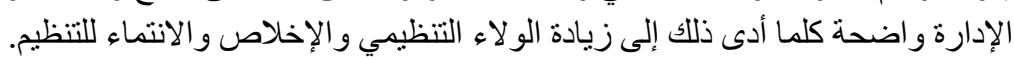

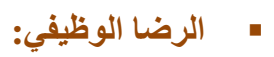

يرى" هيرزبرغ" HERZBERG أن الرضا الوظيفي يمكن تحديده بمعرفة الشعور بالإنجاز و الاعتبار و المسؤولية و إمكان التقدم في

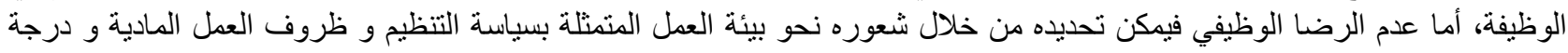

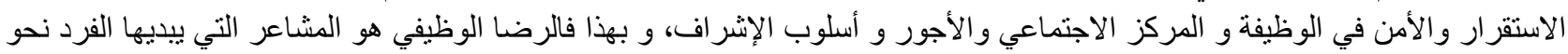

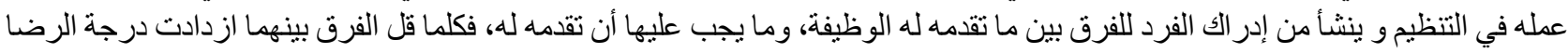

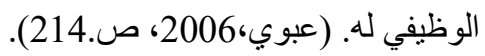

2. 2 2 2

ينجم عن ولاء العاملين لتظيماتهم عدة مخرجات تكون في معظمها سلوكا ايجابيا يعود عليهم و على تتظيماتهم بالفو ائد الكبيرة، ومن ابرز هذه المخرجات و أكثر ها تأثنر ا في حياة المنظمات لفئ ما يلي: - شعور العاملين بروح معنوية عالية: لقد تعدد تعاريف الروح المعنوية، فمنهم من يرى أن الروح المعنوية هو" ذلك الاستعداد الوجداني الذي يهيئ للعاملين مشاطرة أقرانهم

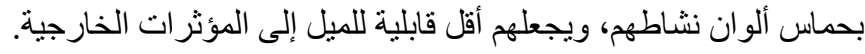




$$
\text { - الحد من تشرب الموظقين: }
$$

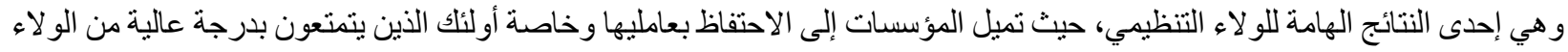

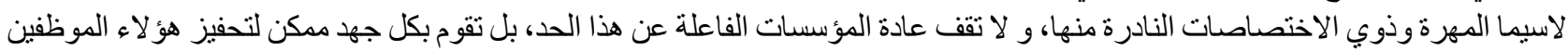

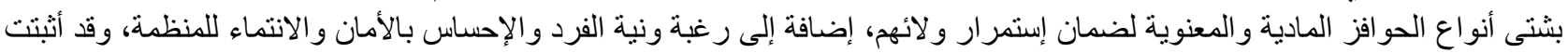

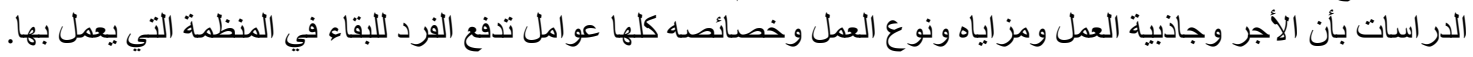

$$
\text { " الانجاز المباع: }
$$

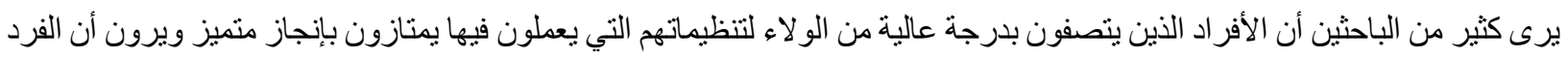

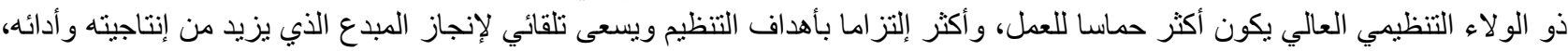

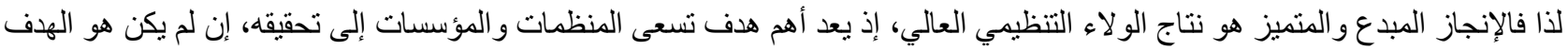

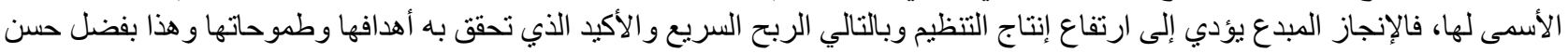

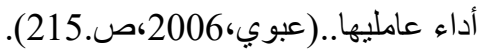

دراسات سابقة الار اسات السابقة المتعلقة بموضوع بالقيادة الاخلاقية:

3. دراسة الجراح (2015)

و هي بعنوان: اخلاقيات التعليم في ضوء التربية الحديثة ومدى التزام القيادات في الجامعة الأردنية وجامعة اليرموك بها. هدفت الدر اسة إلى الكثف عن اخلاقيات مهنة التعليم ومدى التزام باخلاقيات مهنة التعليم، واستخدم الباحثان المنهج الوصفي التحليلي.

$$
\begin{aligned}
& \text { ونوصلت الدر اسة الى النتائج التالية: } \\
& \text { • عدم وجود أثر للجامعة في الالتز ام بأخلاقيات مهنة التعليه. } \\
& \text { • هناك ضعف في توفر بعض الاخلاقيات. } \\
& \text { • وجود ضعف في مجال أخلاقيات تعامل الموظفين مع المدراء. }
\end{aligned}
$$

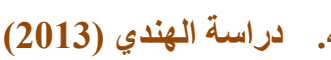

و هدفت در اسة الهندي (2013) إلى التعرف على درجة ممارسة مديري الددارس الثانوية بمحافظات غزة للقيادة الأخلاقية و علاقتها بدرجة

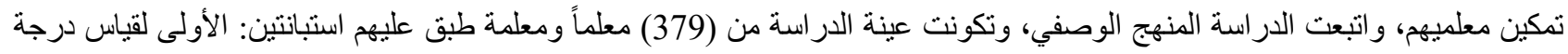

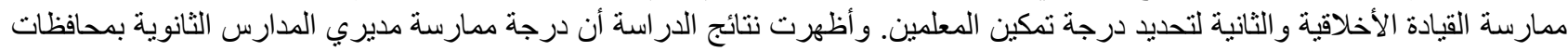

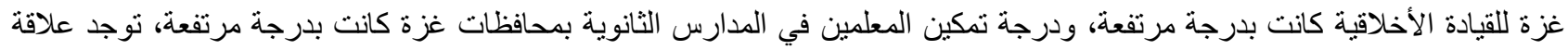

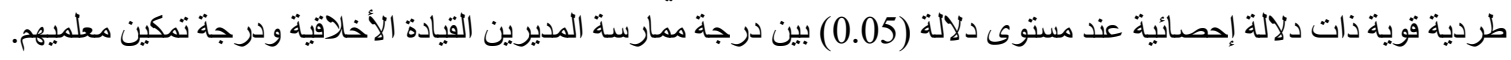

$$
\text { 5. }
$$

وأجرى العتيبي (2013) دراسة إلى هدفت التعرف على درجة ممارسة مديري المدارس الثانوية للقيادة الأخلاقية و علاقتها بقيمهم التتظيمية

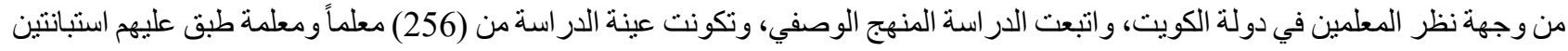

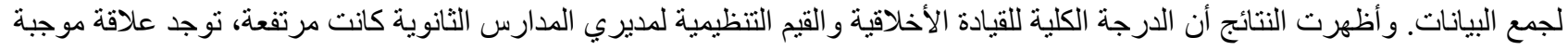
ذات دلالة إحصائية بين درجة ممارسة مديري المدارس الثانوية للقيادة الأخلاقية وقيمهم التنظيمية.

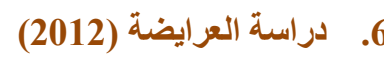

و هدفت در اسة العر ايضة (2012) إلى التعرف على مستوى ممارسة مديري المدارس الثانوية الحكومية في عمان للقيادة الأخلاقية، و علاقته

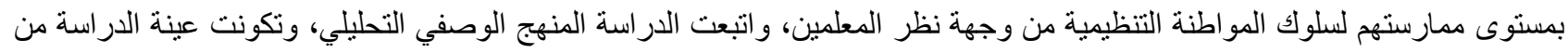

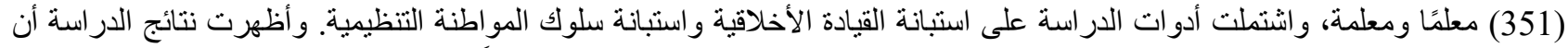

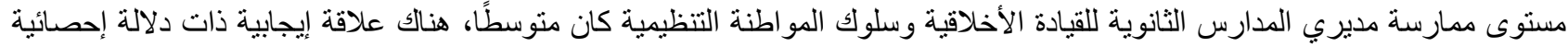

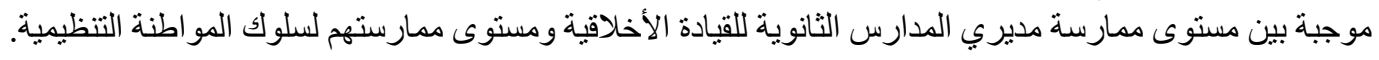

$$
\text { 7. }
$$

و هدفت در اسة الثريفي و التتح (2011) إلى التعرف على درجة ممارسة مديري المدارس الثانوية الخاصة بإمارة الثشارقة للقيادة الأخلاقية وعلاقتها بدرجة تمكين المعلمين، واتبعت الدراسة المنهج المسحي الارتباطي، وتكونت عينة الدراسة من (610) معلم ومعلمة طبق عليهم التهرية 


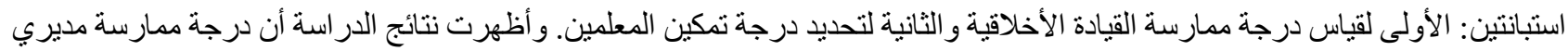

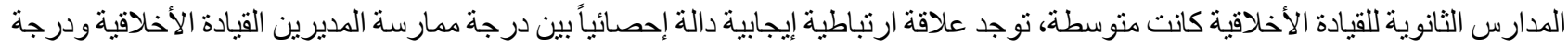

تمكين المعلمين.

8.

عنوان الدر اسة: تطوير مدونة الأخلاقيات الأكاديمية للأستاذ الجامعي من وجهة اعضاء هيئة التدريس والطلبة في الجامعة الاردنية عمان.

هدفت إلى تحديد السلوك الخلقي للأستاذ الجامعي في المجال الأكاديمي، كما يراه أعضاء هيئة التدريس في الجامعة الأردنية، ومعرفة ما إذا

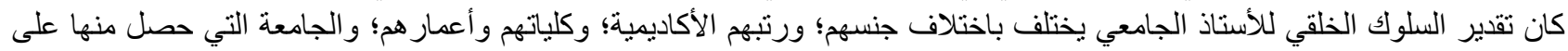

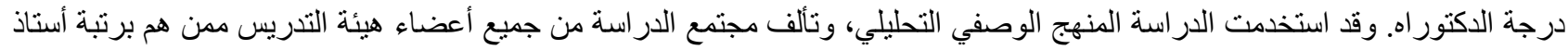

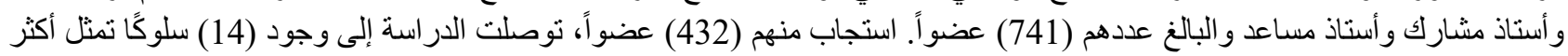

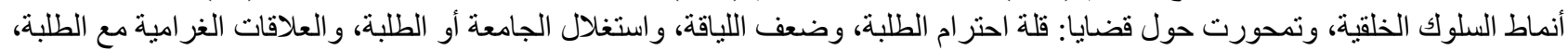

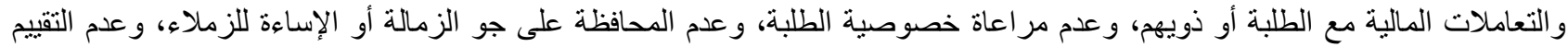

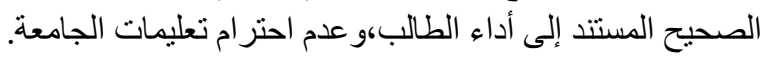

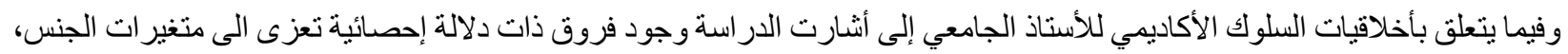

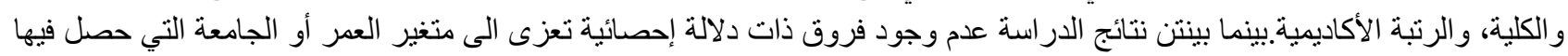

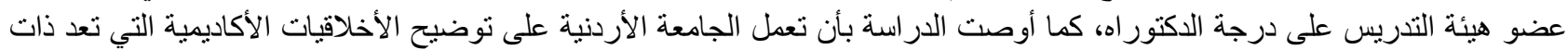
أهية في الارتقاء بالعمل التعليمي الجامعي، وكذللك إجر اء المزيد من الدراسات حول هذا الموضو علئ لما له من أثر في البيئة الجامعية و التعليم العالي بشكل عام.

الار اسات السابقة المتعلقة بموضوع بالو لاء التنظيمي

1. 1 دراسة حمدان (2008)

عنوان :العلاقة بين الحرية الأكاديمية والو لاء التتظيمي كما ير اها اعضاء الهيئة التدريسية في الجامعات الفلسطينية ـ الضفة الغربية.

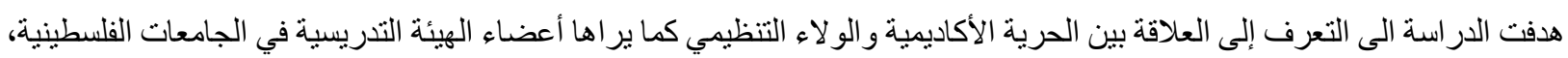

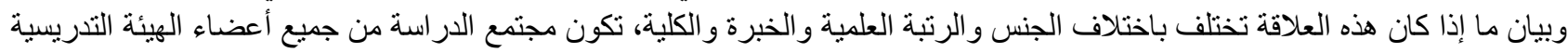

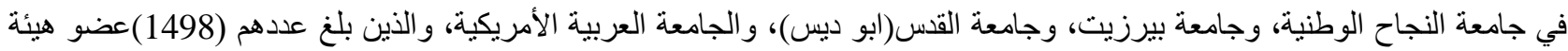

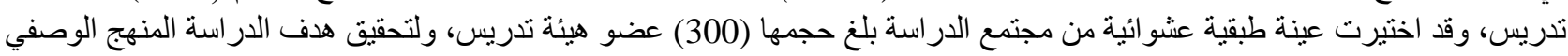
التحليلي، واستخدمت الباحثة استبانتين :الأولى لقياس الحرية الأكاديمية، و الثانية لقياس الو لاء التئية التنظيمي .وقد تكونت الاستبانتان من (58) فقرة.

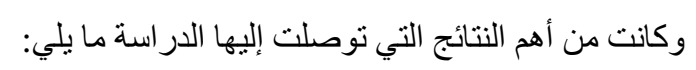

\% • ل انوجد علاقة ذات دلالة إحصائية بين الحرية الأكاديمية والو لاء التنظيمي لاى أعضاء الهيئة التدريسية في الجامعات الفلسطينية.

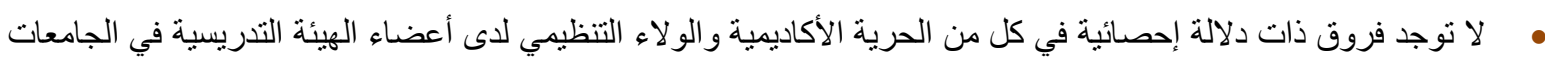

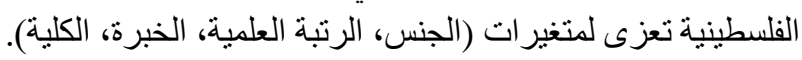

2. 2004 دراسة العمري (2004)

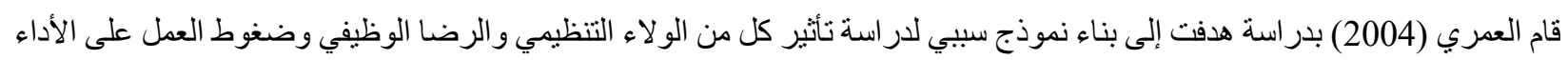

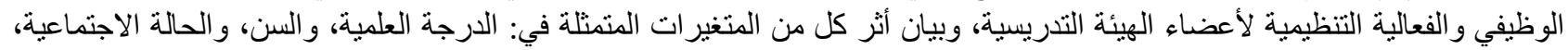

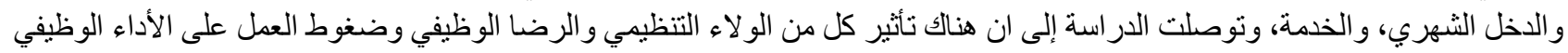

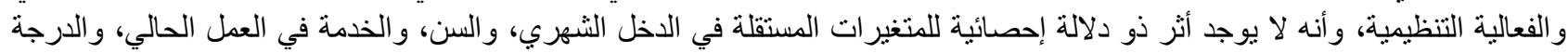

العلمية، على مستوى الو لاء التنظيمي.

3.

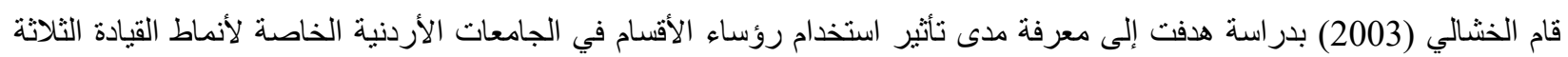

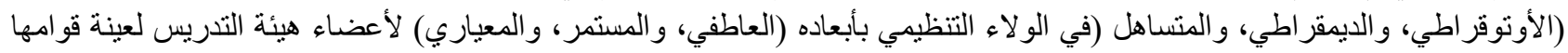

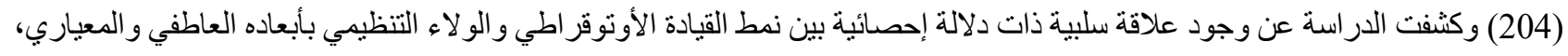


ولم نظهر هذه العلاقة مع الو لاء المستمر، وأن هناك علاقة إيجابية ذات دلالة إحصائية بين نمط القيادة الديمقر اطي و الو لاء التنظيمي بأبعاده

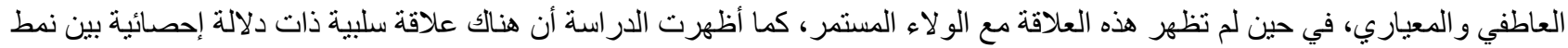

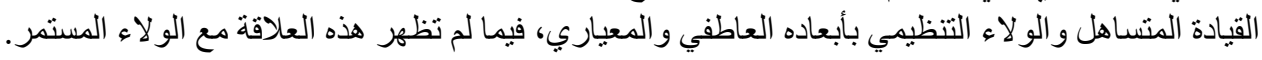

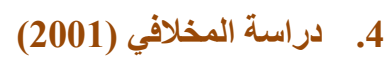

وفي در اسة قام بها المخلافي (2001) هدفت إلى الكثف عن مدى وجود على علاقة بين الو لاء التنظيمي المهني لعضو هيئة التندريس في كليات

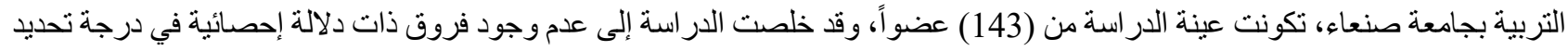

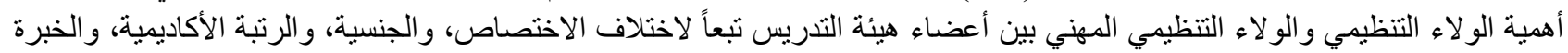

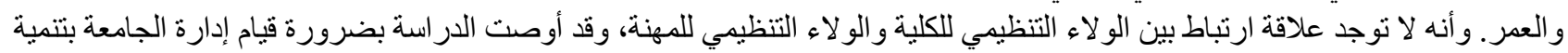

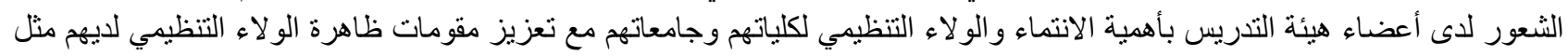

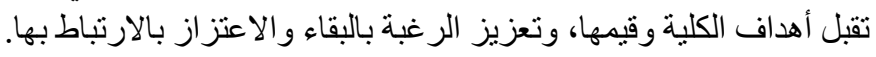

الاراسات الاجنبية

1 1

هدفت إلى التعرف على العلاقة بين درجة ممارسة مديري المدارس في الو لايات المتحدة للقيادة الأخلاقية ومستويات الكفاءة الجماعية من

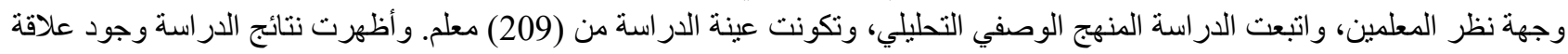
ارتباطية قوية بين درجة ممارسة سلوك القيادة الأخلاقية والكفاءة الجماعية للمعلمين.

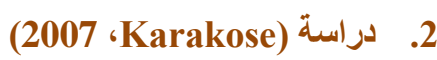

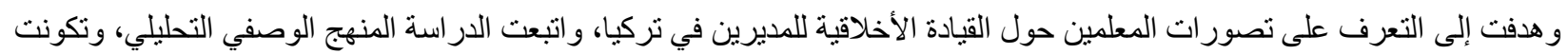

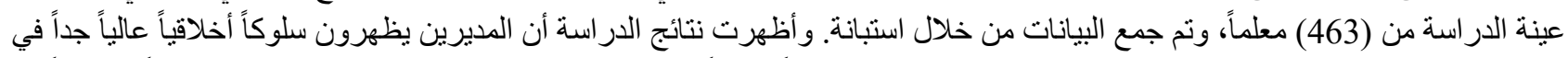

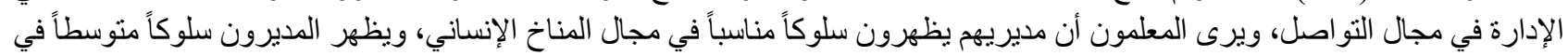
مجال صناعة القرار.

3.

هدفت إلى قياس مستوى الو لاء التنظيمي لدى أعضاء هيئة التدريس و التعرف إلى العلاقة بين الو لاء التباء التظيمي بأبعاده (الو لاء التنظيمي

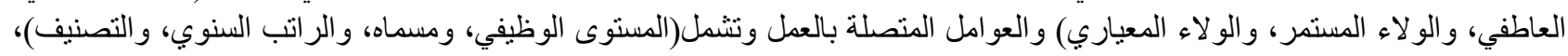

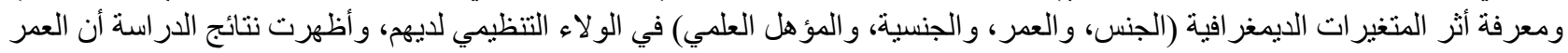

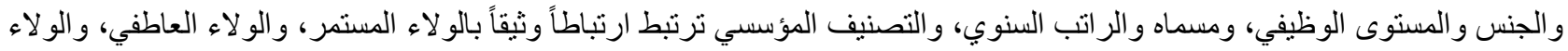

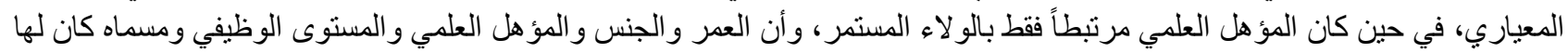
نأثير مهم في الو لاء المستمر.

التُطيق على الاراسات السابقة

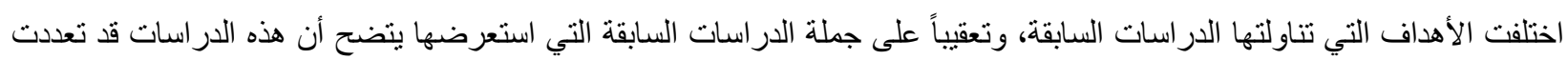

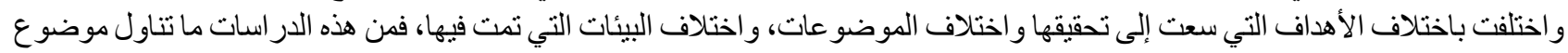

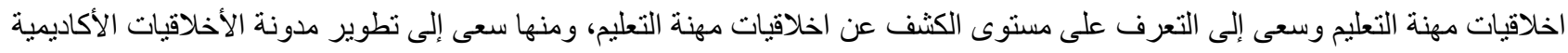

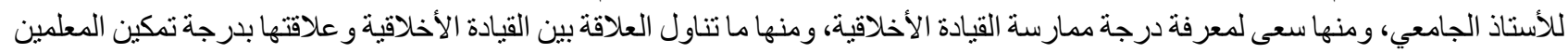

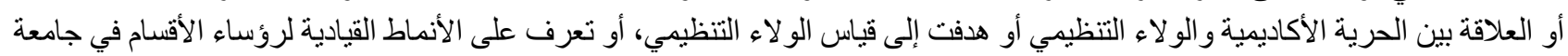

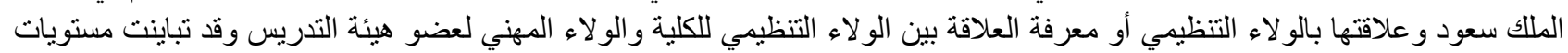

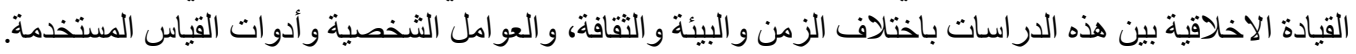

دراسات تثناولت موضوع القيادة الاخلاقية كدراسة كل من:

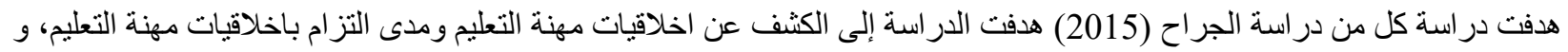

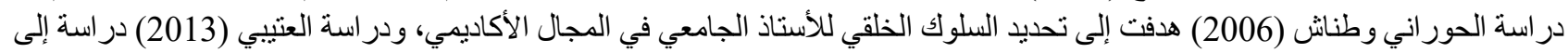

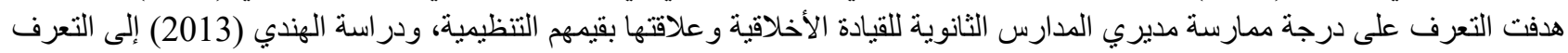

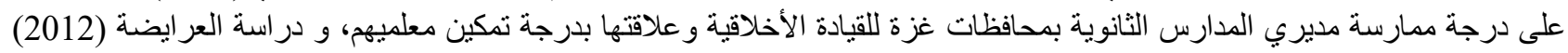

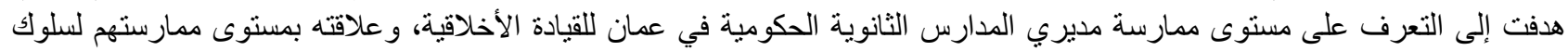
المو اطنة التنظيمية. 


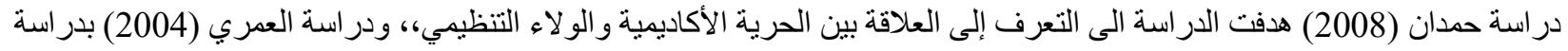

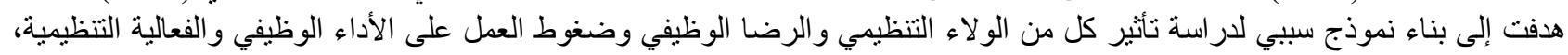

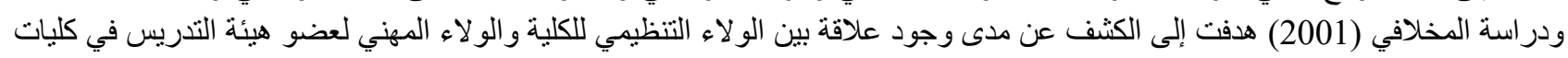

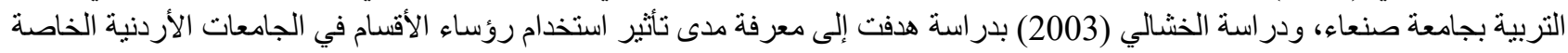

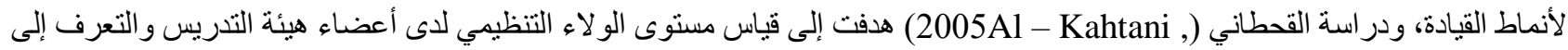

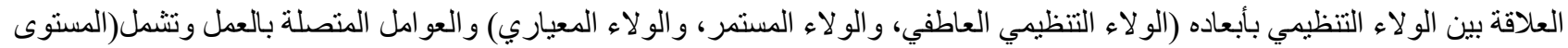

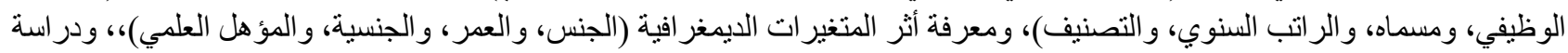
(2011،Bowers)

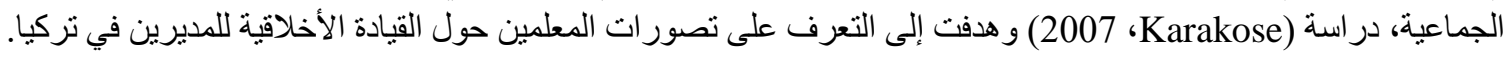

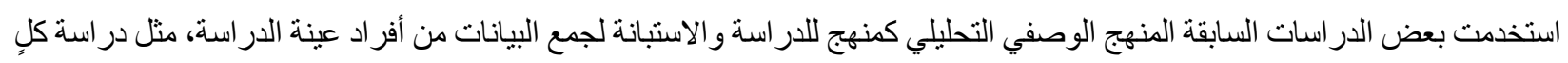

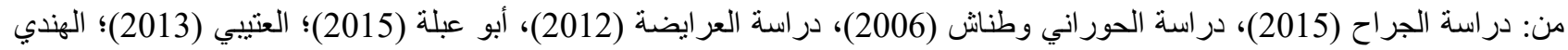

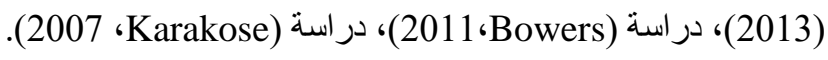

تباينت الدر اسات في تحديد أثر المتغير ات الثخصية مثل: الجنس والخبرة والمؤهل العلمي على كل من القيادة الاخلاقية و الو لاء التنظيمي.

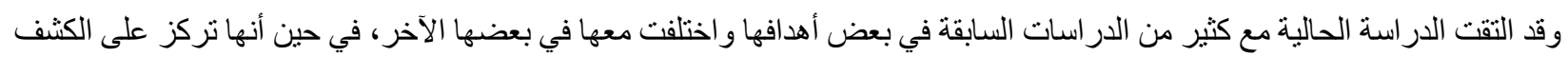

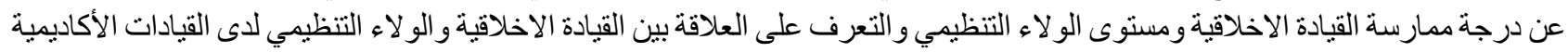

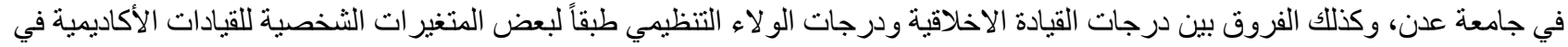

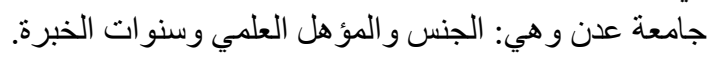
وقد استفادت الدراسة الحالية من الدراسات السابقة في الآتي:

• • كتابة الإطار النظري فيما يتعلق بموضو عات الدراسة الحالية.

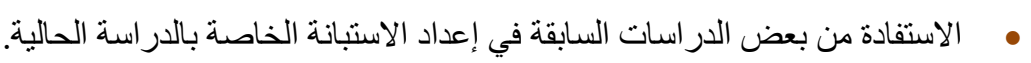

• الاستفادة من توصيات واقتر احات بعض الدراسات السابقة في التعرف على الجوانب التي تستحق البحث.

Field Study Procedures إجراء|ت الدراسة الميدانية

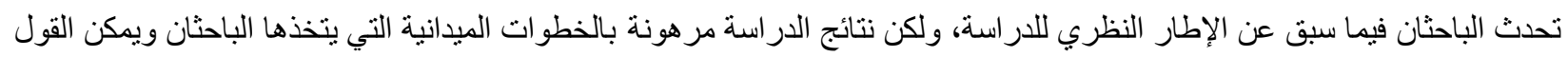

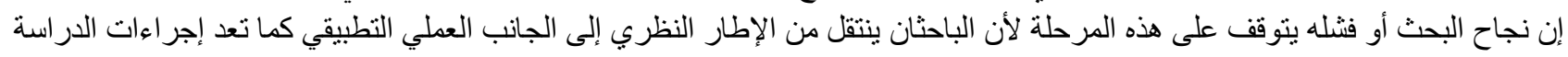
من الركائز المهمة في البحث العلمي.

ويهدف الباحثان في هذا الفصل إلى توضيح الإجر اءات الآتية:

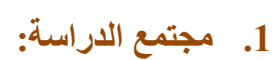

يقصد بمجتمع الدراسة كما ذكر (عبيدات وآخرون,2003م،223) بأنه "جميع الأفر اد أو الأشخاص أو الأشياء الذين يكونون موضوع مشكلة البحث"

\begin{tabular}{|c|c|}
\hline العدد & فئات المجتمع \\
\hline 4 & رئيس جامعة ونو ابه \\
\hline 23 & عمداء الكليات \\
\hline 76 & نواب عمداء الكليات \\
\hline 16 & مديرو المر اكز العلمية التعليمية ونو ابهم \\
\hline 119 & الإجــــــــالي \\
\hline
\end{tabular}


الجدول (2): جدول يوضتح عدد الاستبانات الموزعة والعائدة لمجتمع الدراسة

\begin{tabular}{|c|c|c|c|c|c|}
\hline \multicolumn{3}{|c|}{ الاستباتـات العائدة } & \multicolumn{2}{|c|}{ الاستباتات الموزعة } & \multirow{2}{*}{ القيادات الأكاديمية } \\
\hline النسبة من الإجمالي & النسبة من الفئة & العدد ال العد & النسبة من الإجمالي & العدد & \\
\hline$\% 0$ & $\% 0$ & 0 & $\% 0.84$ & 1 & رئيس جامعة \\
\hline$\% 3$ & $\% 67$ & 2 & $\% 2.52$ & 3 & نواب رئيس الجامعة \\
\hline$\% 21$ & $\% 75$ & 15 & $\% 19.33$ & 23 & عمداء الكليات \\
\hline$\% 69$ & $\% 61$ & 48 & $\% 63.86$ & 76 & نواب عمداء الكليات \\
\hline$\% 7$ & $\% 31$ & 5 & $\% 13.45$ & 16 & مدراء المراكز العلمية التعليمية ونوابهر \\
\hline$\% 100$ & - & 70 & $\% 100$ & 119 & الإجـــــــــلي \\
\hline
\end{tabular}

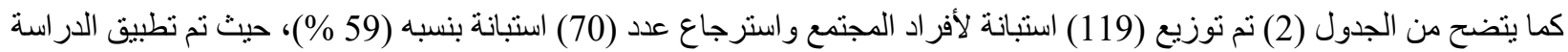

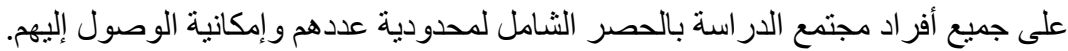

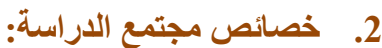

بما أن الباحثان قد أوضح مجتمع الدر اسة، لزم عليه تبيان خصائص هذا المجتمع، ويمكن توضيح خصائص مجتمع الدراسة ونسبها المئوية حسب متغيرات الدر اسة فيما يلي: أولاً: فيما يتعلق بمتغير الوظيفة:

جدول (3): يبين خصائص أفراد مجتمع الار اسة ونسبها المئوية حسب متغير الوظيفة

\begin{tabular}{|c|c|c|}
\hline النسبة المئوية \% & العدد ال العد & الوظيفة \\
\hline$\% 3$ & 2 & نواب رئيس الجامعة \\
\hline$\% 21$ & 15 & عميد كلية \\
\hline$\% 69$ & 48 & نائب عميد كلية \\
\hline$\% 7$ & 5 & مدير مركز أو نائب \\
\hline 100.0 & 70 & الإجمالي \\
\hline
\end{tabular}

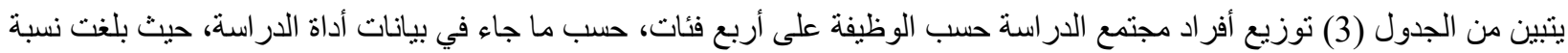

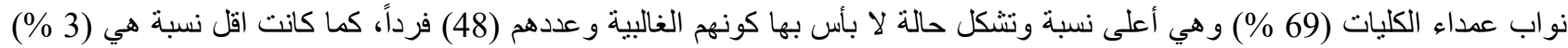

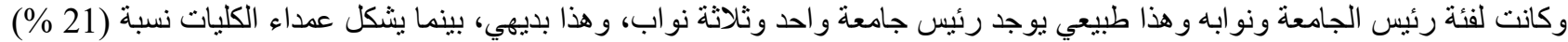

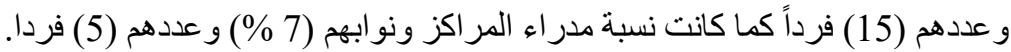
ثُانياً: فيما يتُطق بمتثير اللقب العلمي:

جدول (4): يبين خصائص أفراد مجتمع الاراسة ونسبها المئوية حسب متغير اللقب العلمي

\begin{tabular}{|c|c|c|}
\hline النسبة المنوية \% & العدد & اللقب العلمي \\
\hline 14 & 10 & أستاذ \\
\hline 26 & 18 & أستاذ مشارك \\
\hline 60 & 42 & أستاذ مساعد \\
\hline 100 & 70 & المجموع \\
\hline
\end{tabular}

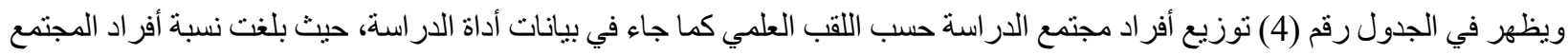

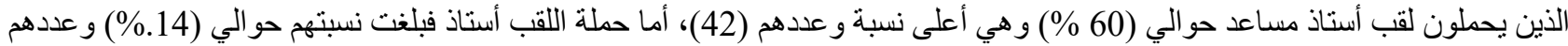
(10) فرداً و هي أقل نسبة و هذا طبيعي لأنها أعلي درجة وهل علية، أما حملة اللقب أستاذ مشارك فبلغت نسبتهم حو الي (26\%) و عددهم (18) فرداً ثُاثثاُ: فيما يتُطق بمتثير سنوات الخبرة:

جدول (5): يبين خصائص أفر اد مجتمع الدراسة ونسبها المئوية حسب متغير سنوات الخبرة

\begin{tabular}{|c|c|c|}
\hline النسبة المنوية \% & العدد & سنوات الخبرة \\
\hline 31 & 22 & اقل من خمس سنوات \\
\hline 29 & 20 & من 5 إلى 10 سنوات \\
\hline 20 & 14 & من 11 إلى 15سنة \\
\hline 20 & 14 & أكثر من 15 سنة \\
\hline 100.0 & 70 & الإجمالي \\
\hline
\end{tabular}




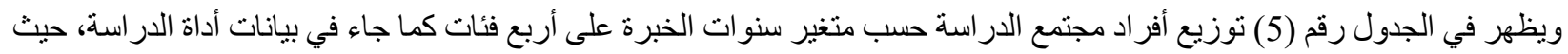

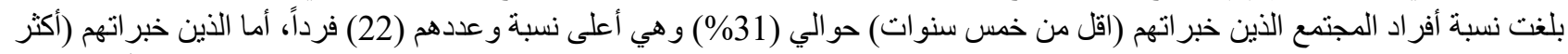

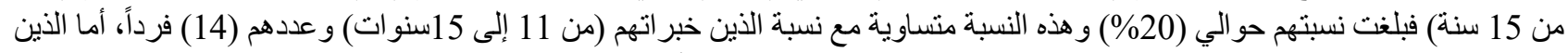

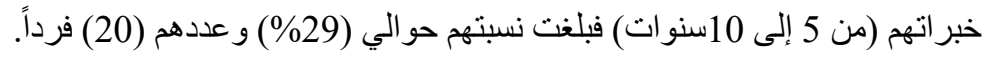

1 أدماة الدراســة:

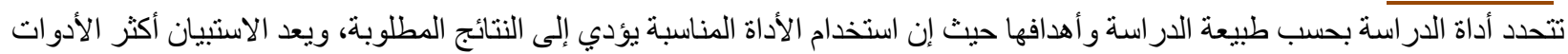

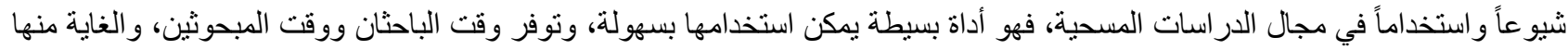

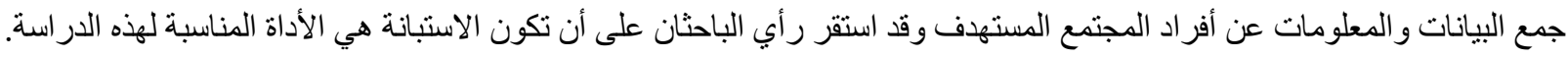

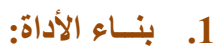

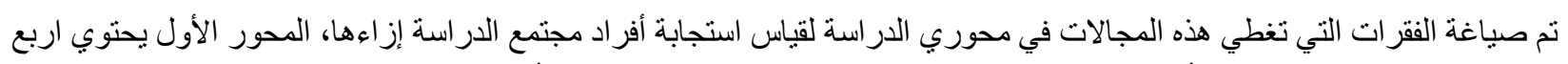

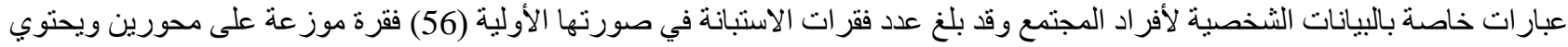

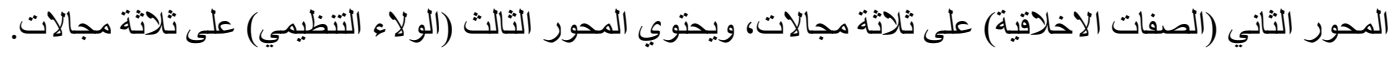

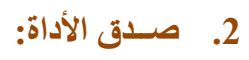

\subsection{1. صدق المحكمين (الصدق الظاهري):}

حيث تم عرض الاستبانة على مجموعة من المحكمين نألفت من (11) من المتخصصين في مجال الأصول والإدارة التربوية وهم ممن يحملون مؤهل الدكتور اله

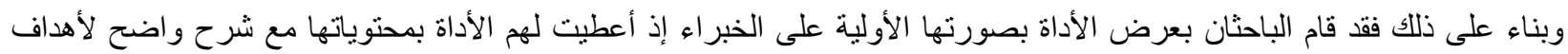

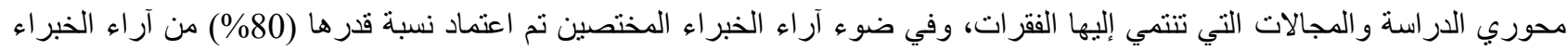

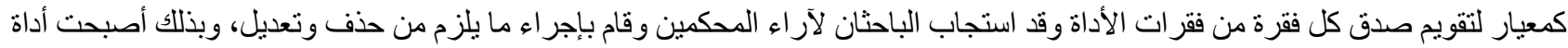

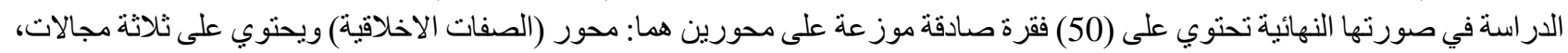
ومحور (الو لاء التنظيمي) ويحتوي على ثلاثة مجالات.

2.2. 2.2 صدق الاتساق الداخلي Internal Validity:

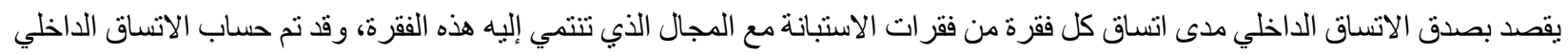

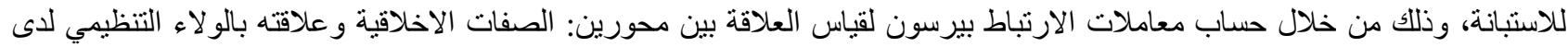

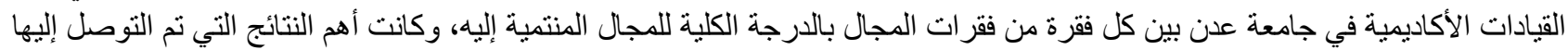
موضحة في الجدول الآتي:

جدول (6): يوضح صدق الاتساق الداخلي بمعامل ارتباط كل فقرة بالارجة الكلية للمجال لمحوري القيادة الأخلاقية والولاء التنظيمي

\begin{tabular}{|c|c|c|c|c|c|}
\hline \multicolumn{3}{|c|}{ المحور الثاني: الولاء التنظيمي } & \multicolumn{3}{|c|}{ المحور الأول: القيادة الاخلاقية } \\
\hline \multicolumn{3}{|c|}{ مجال الأيمان بالعمل } & \multicolumn{3}{|c|}{ مجال الصفات الثخصية الاخلاقية } \\
\hline$* * 0.789$ & غرس الإخلاص والولاء من قبل & 27 & $* * 0.825$ & يطبق ويطور المنظومة الأخلاقية & 1 \\
\hline$* * 0.776$ & أحزص الجأن أكون وضعل أصواً فاعلاً في & 28 & $* * 0.712$ & يتحرى الصدق في تعامله مع العاملين & 2 \\
\hline$* * 0.861$ & أكلف بأعمال تتناسب مع طبيعة & 29 & $* * 0.867$ & ينجز المهام المطلوبة منه بصدق . & 3 \\
\hline$* * 0.742$ & أشعر بتقارب بين أهدافي وأهداف .أجافة & 30 & $* * 0.864$ & يراعي الظروف الإتسانية والطارئة & 4 \\
\hline$* * 0.852$ & ـاحترم الثقافة التنظيمية في الجامعة. & 31 & $* * \mathbf{0 . 8 2 1}$ & يمد يد العون والمساعدة للعاملين. & 5 \\
\hline$* * 0.880$ & أؤمن بأهداف الجامعة وجدوى & 32 & $* * 0.863$ & يهتم بمظهره الخارجي من حيث & 6 \\
\hline$* * 0.869$ & أتبني أهداف الجامعة كمؤشر على العلى & 33 & $* * 0.755$ & يتراجع عن قراره بكل ثقا ثبت علدم & 7 \\
\hline$* * 0.856$ & أدافع عن الجامعة وسمعتها. & 34 & $* * 0.756$ & 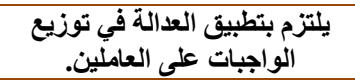 & 8 \\
\hline \multicolumn{3}{|c|}{ مجال الاستعداد للعمل } & $* * 0.834$ & يتقبل نقد الأخرين برحابة صدر. & 9 \\
\hline$* * 0.862$ & أحرص على إبراز الجوانب الايجابية & 35 & \multicolumn{3}{|c|}{ مجال الصفات الادارية الاخلاقية } \\
\hline$* * 0.864$ & أقدم المقترحات البناءة لتذليل الصعاب ألجامعة & 36 & $* * 0.837$ & يركز على قيم العاملين وأخلاقياتهم & 10 \\
\hline
\end{tabular}




\begin{tabular}{|c|c|c|c|c|c|}
\hline$* * 0.702$ & ـأتبادل الخبرات مع زملائي بالجامعة. & 37 & $* * 0.855$ & يحفز العاملين على اداء العمل بدقة & 11 \\
\hline$* * 0.766$ & أقوم بأداء مهماتي الوظيفية على . أكمل وجه & 38 & $* * 0.789$ & يتفقد العاملين ويطمئن عليهم أثناء & 12 \\
\hline$* * 0.826$ & .ألتزم بمواعيد الدوام بالجامعة. & 39 & $* * 0.763$ & يشعر العاملين بالاستقرار الوظيفي دورهي في الجامعة & 13 \\
\hline$* * 0.852$ & . أحرص على عدم التغيب عن العمل & 40 & $* * 0.873$ & خلالى التزامقه بالمبادئ الأخلاقية منة & 14 \\
\hline$* * 0.892$ & أتطلع للتصيزة في الجامعةبة. وظيفية & 41 & $* * 0.842$ & يوضح أولويات العمل للعاملين بشكل & 15 \\
\hline$* * 0.739$ & 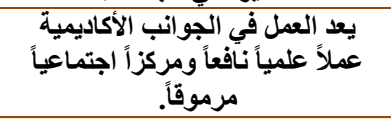 & 42 & $* * 0.842$ & لا يتردد في محاسبة المقصرين بعد & 16 \\
\hline \multicolumn{3}{|c|}{ مجال الاعتزاز بالعمل } & $* * 0.847$ & يستخدم الأسلوب الإيمقراطي في إلجامعة & 17 \\
\hline$* * 0.842$ & أرغب في الاستمر ارلي. بالجامعة طيلة & 43 & $* * 0.863$ & 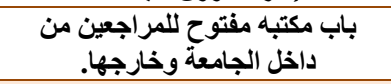 & 18 \\
\hline$* * 0.837$ & أحرص على أن يكون سلوكي منضيط الأكاديمية. & 44 & \multicolumn{3}{|c|}{ مجال العلاقات الانسانية } \\
\hline$* * 0.853$ & أشعر بالعلاقة الأخويةة الحميمة بيني & 45 & $* * 0.828$ & يثارك العاملين مناسباتهم الاجتماعية & 19 \\
\hline$* * 0.855$ & 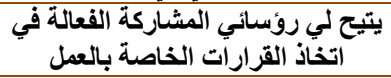 & 46 & $* * 0.832$ & يتمتع بثقة عالية مع العاملين. & 20 \\
\hline$* * 0.788$ & أشعر بالاعتزاز وأنا أتحدث للآخرين & 47 & $* * 0.844$ & يتصف بالنزاهة والمرونة في تعامله & 21 \\
\hline$* * 0.852$ & مناخ العمل في الجامعةًّ التي أنتمي & 49 & $* * 0.835$ & 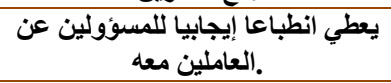 & 22 \\
\hline$* * 0.832$ & هناك توافقاً بين قيمي وقيم الجامعة & $\mathbf{5 0}$ & $* * 0.883$ & يحرص أن يكون أسوة حسنة & 23 \\
\hline & & & $* * 0.769$ & 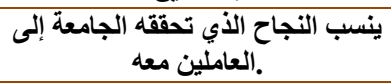 & 24 \\
\hline & & & $* * 0.833$ & يعتمد علي الإنسانية في تعادئ الأخلاقية و الأخرين & 25 \\
\hline & & & $* * 0.873$ & 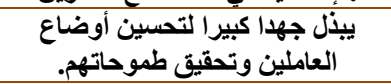 & 26 \\
\hline
\end{tabular}

* * معامل ارتباط معنوي عند مستوى معنوية (0.01)

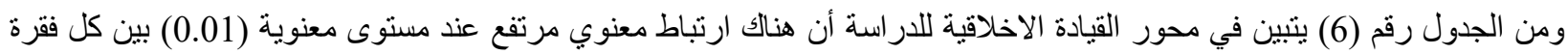

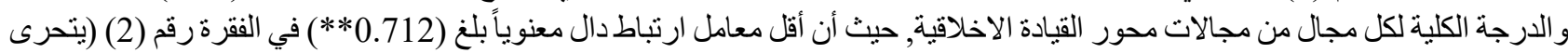

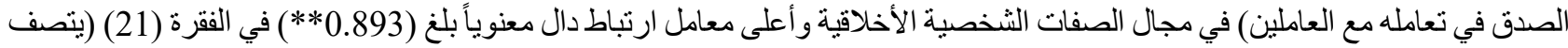

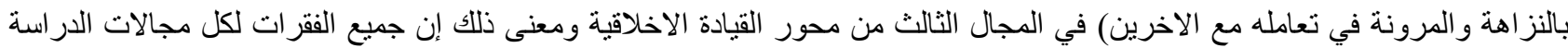
صالحة لهدف الدراسة.

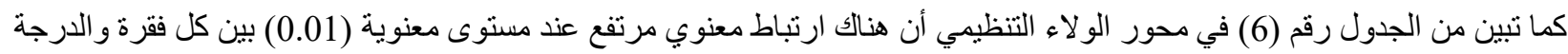

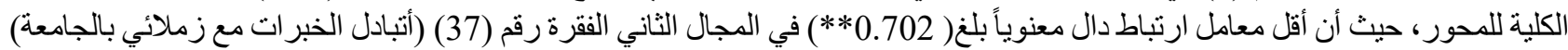
و أعلى معامل ارتباط دال معنوياً بلغ (0.862**) في الفقرة رقم (35) (أحرص على الفى إبراز الجوانب الايجابية للجامعة) ومعنى ذلك إن جميع

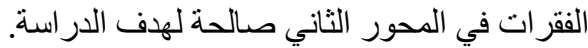

Structure Validity الصدق البنائي 3.2.

للتأكد من صدق الأداة بعد عرضها على المحكمين تم استخدام الصدق الإحصائي البنائي قام الباحثان بحساب صدق الإن الاتساق الداخلي لمحوري

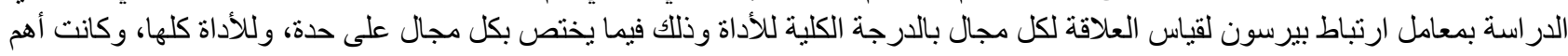
النتائج التي تم التوصل إليها موضحة في الجدول الآتي: 


\begin{tabular}{|c|c|c|c|}
\hline معامل ارتباط & مجالات الدراسة & 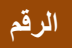 & المحور \\
\hline$* * 0.866$ & الصفات الثخصية الأخلاقية & 1 & \multirow{3}{*}{ محور القيادة الاخلاقية } \\
\hline$* * 0.818$ & الصفات الإدارية الأخلاقية & 2 & \\
\hline$* * 0.826$ & العلاقات الإنسانية & 3 & \\
\hline$* * 0.816$ & الأيمان بالعمل & 1 & \multirow{3}{*}{ محور الولاء التنظيمي } \\
\hline$* * 0.787$ & الاستعداد للعمل & 2 & \\
\hline$* * 0.842$ & الاعتز از بالعمل & 3 & \\
\hline
\end{tabular}

ومن الجدول رقم (7) ينتين في محور الرضا الوظيفي في مجالات الدراسة أن هناك ارتباط معنوي مرتفع عند مستوى معنوية (0.01) بين

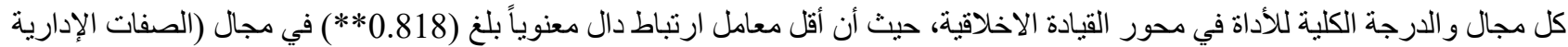

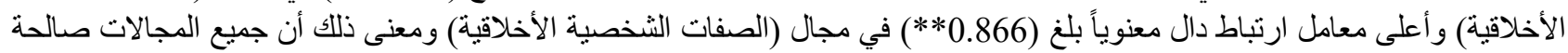
لهدف الدراسة في هذا المحور.

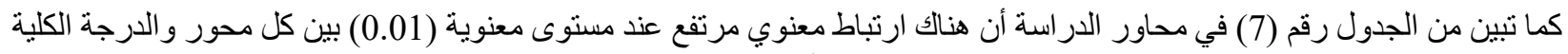

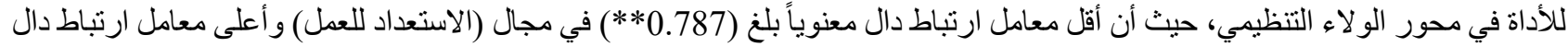

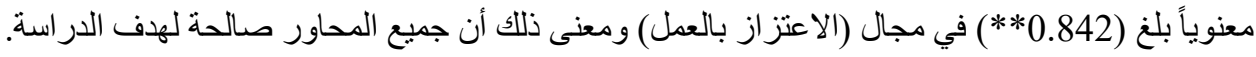

تُبات أداة الدراسة Reliability:

للتحقق من ثبات أداة الدر اسة استخدم الباحثان طريقتين من طرق ثبات الاتساق أو ما يسمى بالثبات الداخلي، الطريقة الأولى التجزئة النصفية و الطريقة الثانية معامل ألفا كرونباخ.

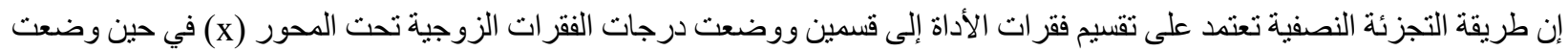

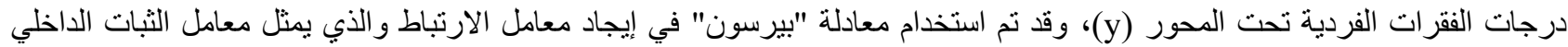
لمحوري الدراسة درجة الممارسة ودرجة الأهمية:

Split Half Method هريقة التجزئة النصفية

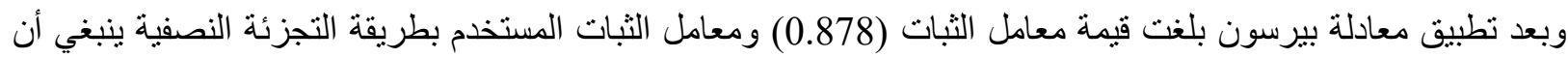

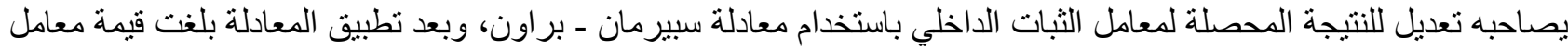
الثبات الداخلي (0.876) و هو معامل ثبات عال يعتمد عليه في جميع البحوث الاجنماعية.

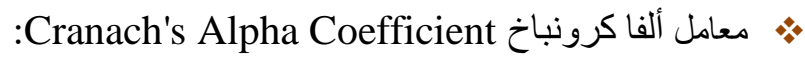
كما استخدم الباحثان لحساب ثبات الأداة بطريقة معامل التجانس ألفا كرونباخ وذللك فيما يختص بكل مجان التهال على حدة، وللأداة

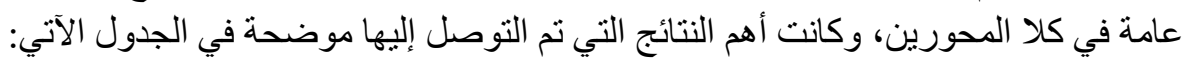

جدول (8): يبين الثبات بطريقة ألفا كرونباخ

\begin{tabular}{|c|c|c|c|}
\hline 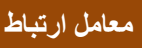 & مجالات الدراسة & الرقم & المحور \\
\hline 0.921 & الصفات الثخصية الأخلاقية & 1 & \multirow{3}{*}{ الاخلّايدة } \\
\hline 0.934 & الصفات الإدارية الأخلاقية & 2 & \\
\hline 0.931 & العلاقات الإنسانية & 3 & \\
\hline 0.940 & الأيمان بالعمل & 1 & \multirow{3}{*}{ لتنظيمي } \\
\hline 0.922 & الاستعداد للعمل & 2 & \\
\hline 0.930 & الاعتز از بالعطل & 3 & \\
\hline 0.927 & \multicolumn{3}{|l|}{ الثبات الكلي لمحور الرضا الوظيفي } \\
\hline 0.924 & \multicolumn{3}{|l|}{ الثبات الكلي لمحور الالتزام التنظيمي } \\
\hline 0.941 & \multicolumn{3}{|l|}{ الثبات الكلي للمحورين رضا الوظيفي والالتزام التتظيمي } \\
\hline
\end{tabular}

يتضح من الجدول رقم (8) أن معاملات التجانس ألفا كرونباخ في محور القيادة الاخلاقية تراوحت في مجالات الدر اسة ما بين (0.934) (0.921)

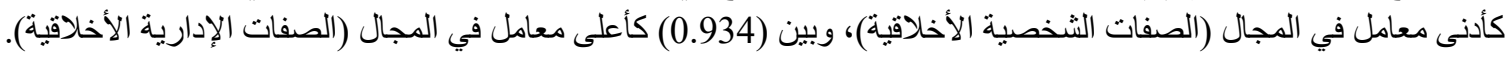


وكما تبين من الجدول (8) أن معاملات التجانس ألفا كرونباخ في محور الو لاء التنظيمي تراوحت في مجالات الدراسة ما بين (0.922) كأدنى معامل في المجال (الاستعداد للعمل)، وبين (0.940) كأعلى معامل في المجال (الأيمان بالعمل).

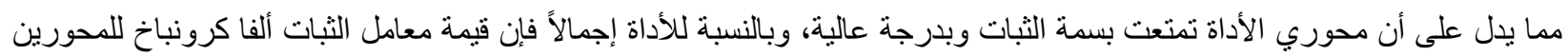
عالية جداً بلغت (0.941) مما يعني أن الأداة إجمالاً تتسم بثبات يمكن الاعتماد على نتأنسائجها. 3. ت تبيق الأداة: بعد التأكد من صدق الأداة وثباتها قام الباحثان بتطبيق هذه الأداة، وتم توزيع (119) نسخة من الاستبيان على جميع مجتمع الدراسة وذلك في العام الجامعي (2020/2019 م).

$$
\text { وقد تم توزيع الأداة وفق الخطوات الآتية: }
$$

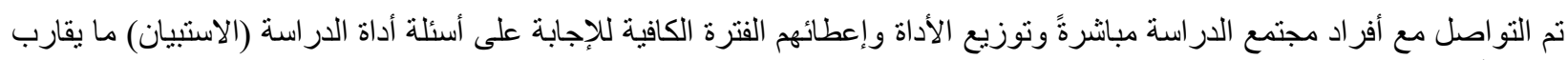

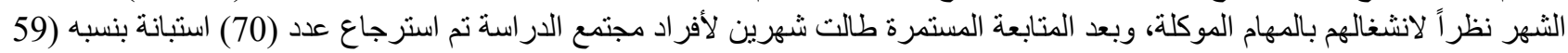

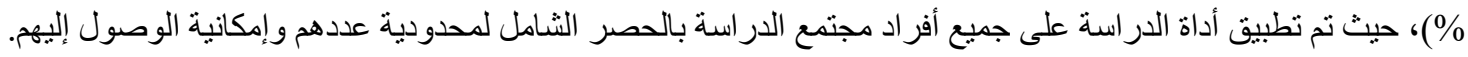

الستخدم الباحثان برنامج الإحصائة: الملائمة في معالجتها واستخلاص باصن النتائج. اعتمد الباحثان على مقياس ليكرت الخماسي في درجة الحدة محكاً لتقدير مجالات الدراسة، ويبين ذلك الجدول الآتي: الجدول (9): يبين درجة الحدة محكاً لتقدير مجالات الاراسة

\begin{tabular}{|c|c|}
\hline درجة الممارسة & مدى المتوسط الحسابي \\
\hline مرتفعة جداً & $5-4.2$ \\
\hline مرتفعة مرة & 3.4 - أقل من 4.2 \\
\hline متوسطة & 2.6 - أقل من 3.4 \\
\hline منخفضة & 1.8 - أقل من 2.6 \\
\hline منخفضة جداً & 1 - أقل من 1.8 \\
\hline
\end{tabular}

وقد أحتسب مدى المتوسط بناءً على أعلى قيمة في مقياس ليكرت و أقل قيمة على وفق معادلة المدى:

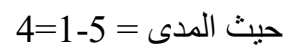
وتحديد طول الفئة بناءً على الددى مقسوماً على عدد الفئات: 4/5=0.8 وبهذا يكون الفرق بين كل قيمة وأخرى (0.8) بحيث يتساوى مدى المتوسط في كل الفئات.

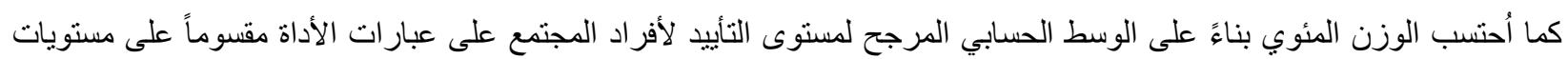

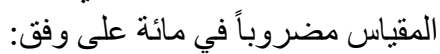

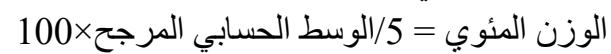

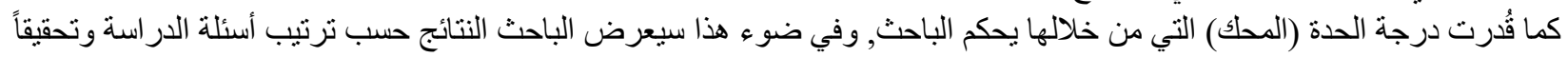

\section{النتائج وتحلئها :Results and Analysis}

سيقوم الباحثان بعرض النتائج التي نم التوصل إليها بعد تطبيق الأداة بناءً على المعالجات الإحصائية التي أجريت على ما تم جمعة وتحليل البيانات، في ضوء أهداف الدراسة التي تبلورت في الإجابة عن الأسئلة الآتية:

نتائج الإجابة عن السؤال الأول:

الذي ينص على: ما درجة ممارسة القيادات الأكاديمية بجامعة عدن للقيادة الاخلاقية من وجهة نظر هم؟

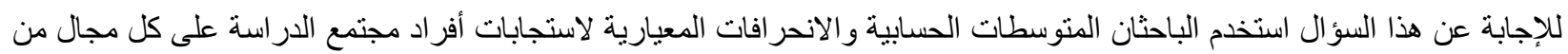

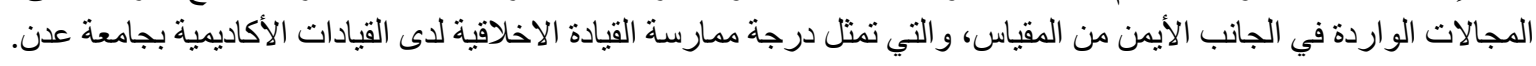
وفيما يلي عرض وتحليل لاستجابات أفر اد مجتمع الدر اسة في كل مجال من مجالات الدر استة المرتبطة بدرجة ممارسة القيادة الاخلاقية لدى القيادات الأكاديمية بجامعة عدن وذللك على النحو الآتي: 


\begin{tabular}{|c|c|c|c|c|c|c|}
\hline المستوى & المئوي\% & المعياري & المتوسط & ترتيب مجالات تثنازلياً حسب & الفقياسة في & الرتبة \\
\hline متوسطة & 65.6 & 0.842 & 3.28 & العلاقات الإنسانية & 3 & 1 \\
\hline متوسطة & 64.4 & 0.841 & 3.22 & الصفات الثخصية الأخلاقية & 1 & 2 \\
\hline متوسطة & 63.4 & 0.873 & 3.17 & الصفات الإدارية الأخلاقية & 2 & 3 \\
\hline متوسطة & 64.47 & 0.852 & 3.22 & \multicolumn{3}{|c|}{ المتوسط العام } \\
\hline
\end{tabular}

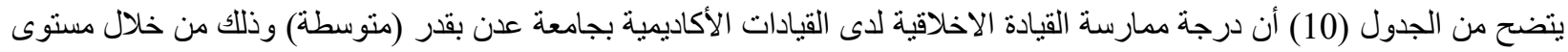

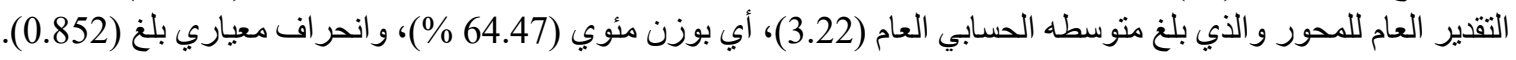

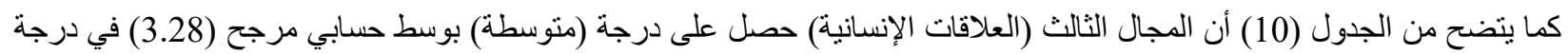

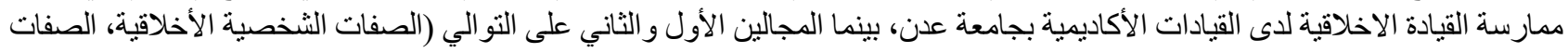

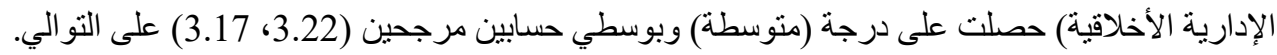

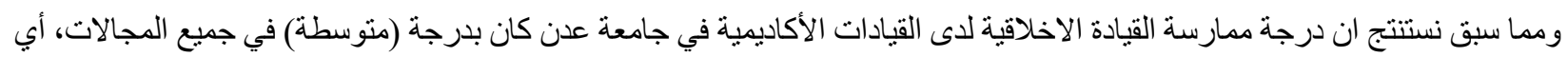

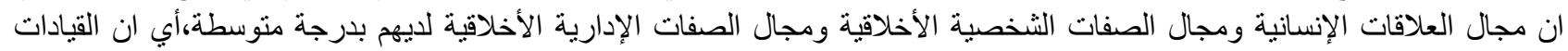

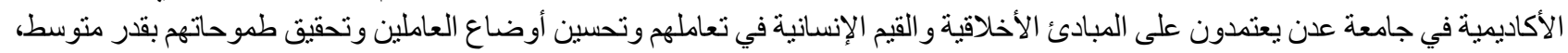

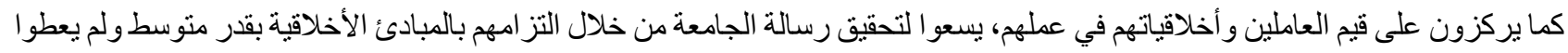

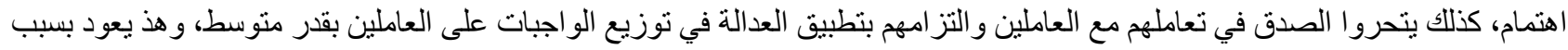

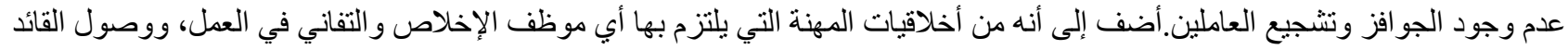

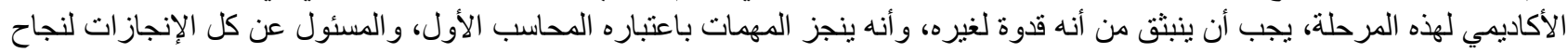

الجامعة.

ويعزى البحث السبب في ذلك إلى كثرة المسئوليات الملقاة على عاتق القائد الأكاديمي، و لأنه المسئول عن جميع الأخطاء و الإنجاز اتلات، فإنها

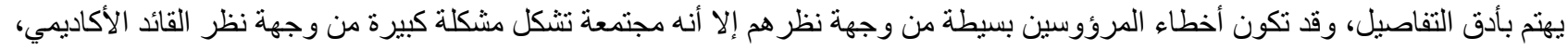

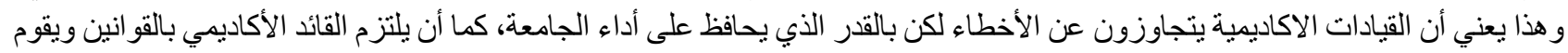
على تطبيقها، كما أنه إن لم يقم القائد بتطبيق القو انين فلاء حاجة لإنة لوجوده، فمن صميم عمله أن يحقق رسالة الجامعة.

نتائج الإجابة عن السؤال الثاني:

الذي ينص على: ما مستوى الولاء التنظيمي لاى القيادات الأكاديمية بجامعة من وجهة نظرهم؟

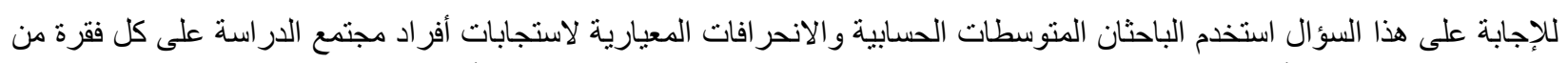

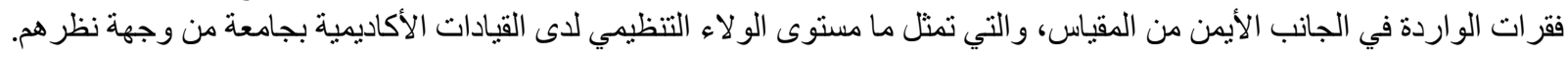

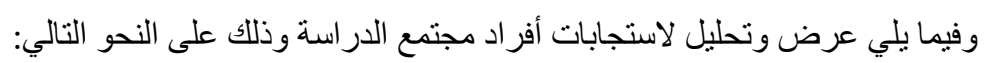

جدول (11): يبين الترتيب التنازلي لفقرات محور الالتزام التنظيمي

\begin{tabular}{|c|c|c|c|c|c|c|}
\hline الممارستة & المئوي \% & الالحعراف & الوسط الحسابي & ترتيب الفقزة تنازلياً حسب المتوسطات & الفقترة في & 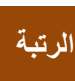 \\
\hline متوسطة & 67.4 & 0.551 & 3.37 & الأيمان بالعمل & 1 & 1 \\
\hline متوسطة & 66.8 & 0.634 & 3.34 & الاستعداد للعمل & 2 & 2 \\
\hline متوسطة & 65.6 & 0.659 & 3. 28 & الاعتزاز بالعطل & 3 & 3 \\
\hline متوسطة & 66.6 & 0.615 & 3.33 & \multicolumn{3}{|c|}{ المتوسط العام } \\
\hline
\end{tabular}

بتضح من الجدول (11) أن مستوى الو لاء التتظيمي للقيادات الأكاديمية في جامعة عدن بمستوى منوسط وذللك من خلال مستوى التقدير

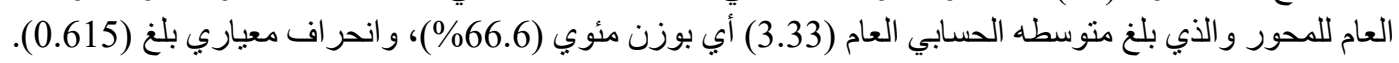

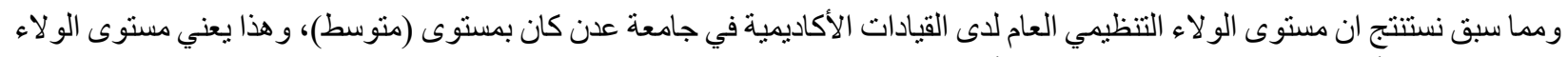

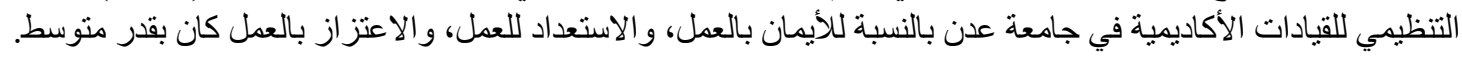

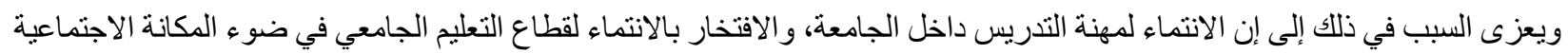

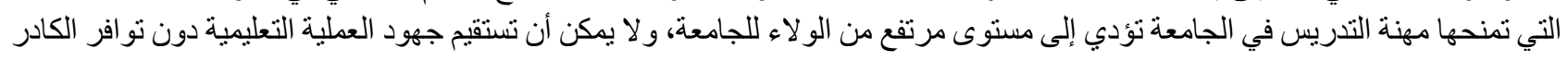


المؤهل و القادر على قيادة مسيرة الجامعية، وعطا القائد الاكاديمي مرتبط إلى حد كبير بو لائه و انتمائه للجامعة، وسعيه الدؤوب لتحقيق رسالة و أهداف الجامعة، مما يدفعه إلى الرغبة في الاستمر ار في العمل الجامعي.

ويرى الباحثان أن القائد الاكاديمي الذي يشعر بالانتماء في مكان عمله يشعر بعدم القدرة على الابتعاد عنه،، و لا شك أن القبادات الأكاديمية

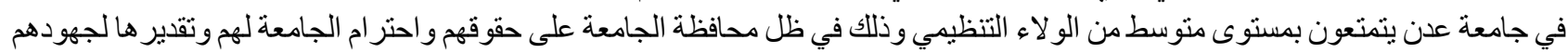

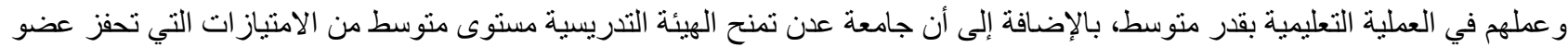
هيئة التدريس على عطائه و انتمائه للجامعة ولأبنائه الطلاب.

نتائج الإجابة عن السؤال الثالث:

الذي ينص على: هل توجد فروق ذات دلالة إحصائية عند مستوى دلالة (0.05) بين استجابات أفراد مجتمع الداراسة حول ممارسة القيادات الأكاديمية بجامعة عدن للقيادة الاخلاقية تعزى للمتفيرات (اللقب العلمي، سنوات دلات الخبرة)؛

للإجابة عن هذا السؤال استخدم الباحثان تحليل التباين الأحادي (One-Way ANOVA) لمعرفة أثر متغيرات (اللقب العلمي، سنوات

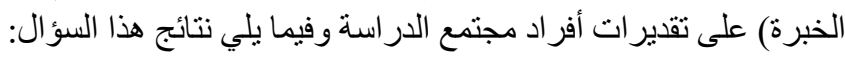

جدول (12): جدول يبين نتائج تحليل التباين الأحادي (One-Way ANOVA) للفروق بين المتغيرات (اللقب العلمي، سنوات الخبرة) ومجالات محور القيادة الاخلاقية

\begin{tabular}{|c|c|c|c|c|c|c|}
\hline مستوى الدلالة & قيمة F & متوسط المربعات & درجة الحرية & المربعات & مصدر التباين & متغيرات الدراسة \\
\hline \multirow{3}{*}{0.146} & \multirow{3}{*}{1.68} & 0.563 & 2 & 2.250 & بين المجمو عات & \multirow{3}{*}{ اللقب العلمي } \\
\hline & & 0.335 & 68 & 43.579 & داخل المجمو عات & \\
\hline & & & 70 & 45.829 & المجموع الكلي & \\
\hline \multirow{3}{*}{0.623} & \multirow{3}{*}{0.17} & 0.168 & 2 & 0.337 & بين المجمو عات & \multirow{3}{*}{ سنو ات الخبرة } \\
\hline & & 0.358 & 68 & 47.292 & داخل المجموعات & \\
\hline & & & 70 & 47.629 & المجموع الكلي & \\
\hline \multirow{3}{*}{0.162} & \multirow{3}{*}{1.6} & 0.527 & 2 & 2.106 & بين المجموعات & \multirow{3}{*}{ المقياس الكلي } \\
\hline & & 0.323 & 68 & 42.006 & داخل المجموعات & \\
\hline & & & 70 & 44.113 & المجموع الكلي & \\
\hline
\end{tabular}

بالنظر إلى الجدول (12) الذي يبين تحليل التباين الأحادي لدالة الفروق في مجالات محور الدر اسة ويتضح بأنه لا توجد فروق ذات دلالة الإلة

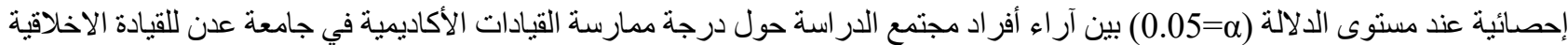
تعزى إلى المتغيرات (اللقب العلمي، سنوات الخبرة) إذ تنشير قيم (F) المحسوبة في المقياس الكلي (1.6) بأنها أصغر من قيمة (F) الجدولية

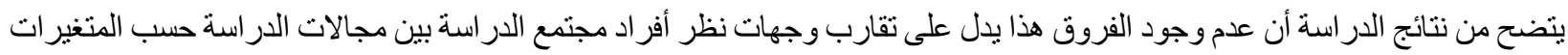

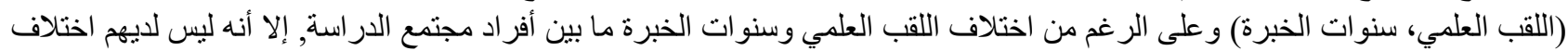

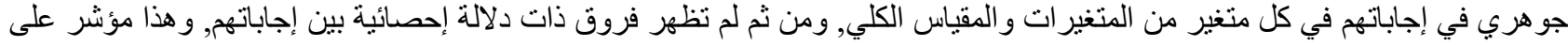

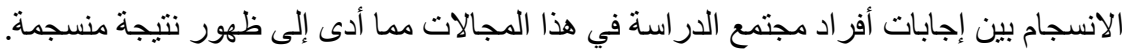

نتائج الإجابة عن السؤال الر (بع:

الذي ينص على: هل توجد فروق ذات دلالة إحصائية عند مستوى دلالة (0.05) بين استجابات أفراد مجتمع الدراسة حول مستوى الولاء التنظيمي تعزى لمتغير ات (اللقب العلمي، سنو دات دلات الخبرة)

للإجابة عن هذا السؤال استخدم الباحثان اختبار تحليل التباين العاملي (One-Way ANOVA) لمعرفة أثر متغيرات (اللقب التبرئ العلمي، سنو ات الخبرة) على تقدير ات أفر اد مجتمع الدراسة وفيمان الئي نتائج هذا السؤ ال: 
جدول (13): جدول يبين نتائج تحليل التباين الأحادي (ANOVA One-Way) للفروق بين المتغيرات (اللقب العلمي، سنوات الخبرة) ومحور الولاء التنظيمي

\begin{tabular}{|c|c|c|c|c|c|c|}
\hline مستوى الدلالة & قيمة F F & متوسط المربعات & درجة الحرية & المربعوت & مصدر التباين & متغيرات الدراسة \\
\hline \multirow{3}{*}{0.652} & \multirow{3}{*}{0.28} & 0.107 & 2 & 0.214 & بين المجموعات & \multirow{3}{*}{ اللقب العلمي } \\
\hline & & 0.378 & 68 & 49.959 & داخل المجمو عات & \\
\hline & & & 70 & 50.173 & الدجموع الكلي & \\
\hline \multirow{3}{*}{0.521} & \multirow{3}{*}{0.20} & 0.355 & 2 & 0.709 & بين المجمو عات & \multirow{3}{*}{ سنوات الخبرة } \\
\hline & & 0.394 & 68 & 51.947 & داخل المجموعات & \\
\hline & & & 70 & 52.656 & الهجموع الكلي & \\
\hline \multirow{3}{*}{0.622} & \multirow{3}{*}{0.16} & 0.172 & 2 & 0.345 & بين المجموعات & \multirow{3}{*}{ المقياس الكلي } \\
\hline & & 0.282 & 68 & 37.231 & داخل المجموعات & \\
\hline & & & 70 & 37.575 & المجموع الكلي & \\
\hline
\end{tabular}

بالنظر إلى الجدول (13) الذي يبين تحليل التباين الأحادي لدلالة الفروق في محور الدراسة ويتضح بأنه لا توجد فروق ذات دلالة إحصائية

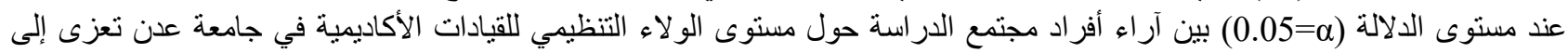
المتغير ات (اللقب العلمي، سنوات الخبرة) إذ تثير قيم (F) المحسوبة في المقياس الكلي (0.16) بأنها أصغر من قيمة (F) الجدولية (2.758).

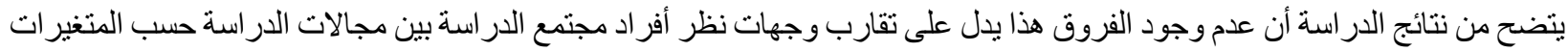

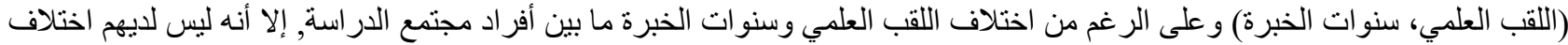

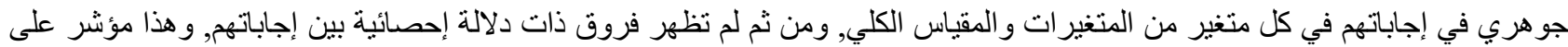
الانسجام بين إجابات أفر اد مجتمع الدر اسة في هذا المجالات فئ مما أدى إلى ظهور نتيجة منسجمة.

نتائج الإجابة عن السؤال الثامس:

الأي ينص على: هل توجد علاقة ارتباطية دالة إحصائياً بين القيادة الأخلاقية والولاء التنظيمي لاى القيادات الأكاديمية بجامعة عدن ؟ للإجابة عن هذا السؤال استخدم الباحثان اختبار بيرسون لإيجاد علاقة القيادة الاخلاقية و الو لاء التنظيمي لدى القيادات الأكاديمية بجامعة

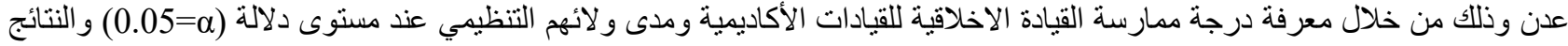

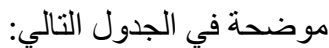

جدول (14): معامل ارتباط بين درجة ممارسة القيادة الاخلاقية وبين مستوى ولائهم التظظيمي

\begin{tabular}{|c|c|c|}
\hline متوى الولاء التنظيمي للقيادات الأكاديمية في جامعة عدن & الإحصاءوات & 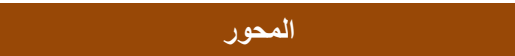 \\
\hline 0.634 & معامل الارتباط & \multirow{3}{*}{ القيادة الاخلاقية للقيادات الأكاديمية في جامعة عدن } \\
\hline 0.000 & القيمة الاحتمالية & \\
\hline 70 & حجم العبنة & \\
\hline
\end{tabular}

قيمة r المحسوبة عند درجة حرية (71) ومستوى دلالة (0.05) بساوي (0.281)

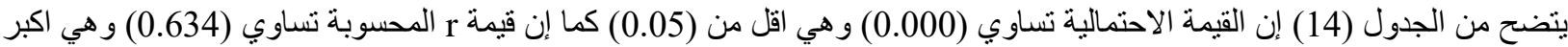

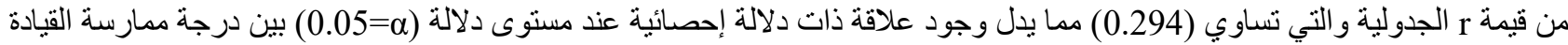

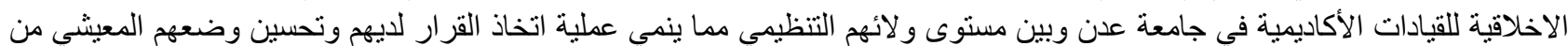

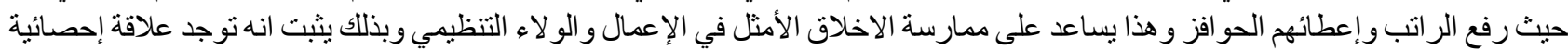
عند مستوى دلالة (a=0.05) بين درجة ممارسة القيادة الاخلاقية للقيادات الأكاديمية في جامعة عدن وبين مستوى و لائهم التنظيمي.

في ضوء ما تم التوصل أليه من خلال نتائج الدراسة الحالية فإن الباحثان يستتنج الآتي: 1. درجة ممارسة القيادة الاخلاقية لاى القيادات الأكاديمية بجامعة عدن بقدر (منوسطة) وذلك من خلال مستوى التقدير العام للمحور و الذي بلغ متوسطه الحسابي العام (3.22)، أبي بوزن مئوي (64.47 \%)، و انحر اف معياري بلغ (0.852).

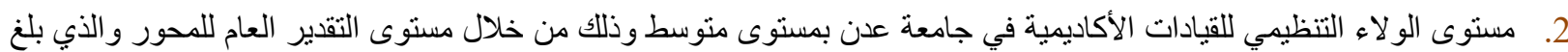

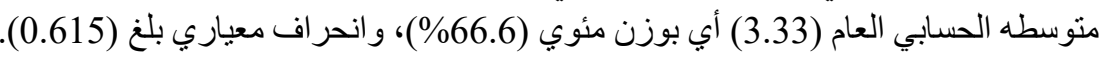


3. لا توجد فروق ذات دلالة إحصائية عند مستوى الدلالة (a=0.05) بين آراء أفراد مجتمع الدراسة حول درجة ممارسة القيادات

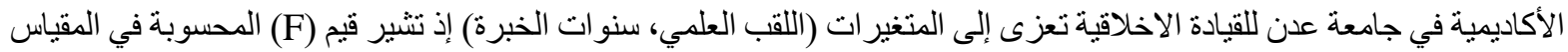
الكلي (1.6) بأنها أصغر من قيمة (F) الجدولية (2.758).

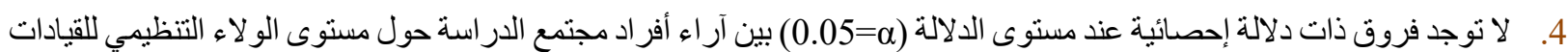

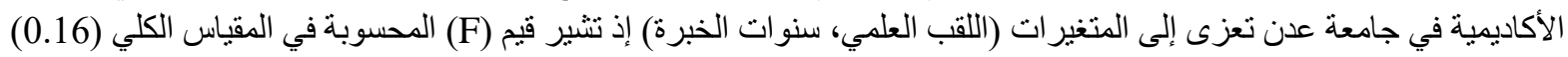
بأنها أصغر من قيمة (F) الجدولية (2.758). 5. وجود علاقة إيجابية ذات دلالة إحصائية عند مستوى دلالة (0.05) بين درجة ممارسة القيادة الاخلاقية للقبادات الأكاديمية في جامعة عدن وبين مستوى و لائهم التنظيمي. الثتوصيات و المقترحات:

1. اثراء مبدأ الاخلاق مع فرق العمل التي يشارك فيها الموظفون و علي اختلاف مستوياتهم الوظيفية، لما له من مردود ايجابي في تعزيز مستوي و لائهم بأهداف الجامعة وتطلعاتها المستقبلية.

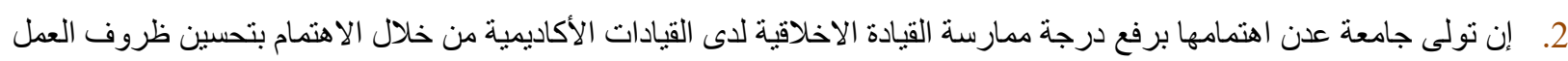

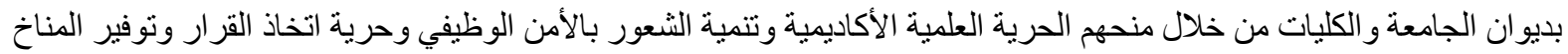
العلمي المناسب للعمل فيها. 3. تقوية العلاقات ما بين قيادات جامعة عدن لما في ذلك من أثر كبير في ارتفاع مستوى الو لاء الوظيفي، وذللك عن طريق الندوات

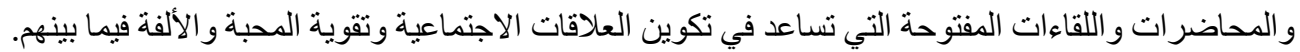

4. تقديم الحو افز التشجيعية وزيادة الدعم المالي لتطوير العمل الأكاديمي وتحسين العملية التعليمية.

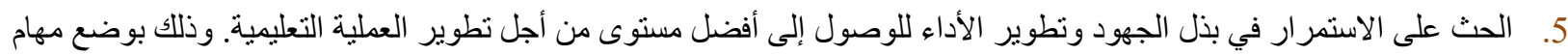

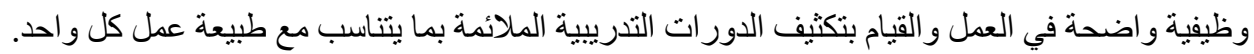

أبو النصر ، دححت محمد، (2014م). القيادة الاخلاقية المتميزة، ط2، المجموعة العربية للتدريب و النشر، القاهرة: مصر. 2] الجر اح، عبدالحميد، (2014). مستويات الذكاء العاطفي لمديرا المدارس الثانوية و أثر ها على الو لاء التنظيمي للمعلمين في العاصمة عمان، رسالة ماجستير غير منشورة، جامعة الثرق الأوسط، عمان الأردن.

الجر اح، مصباح رشيد، (2015). اخلاقيات التعليم في ضوء التربية الحديثة ومدى التزام القبادات في الجامعة الأردنية وجامعة اليرموك بها، رسالة ماجستير غير منشورة، جامعة اليرموك - عمان.

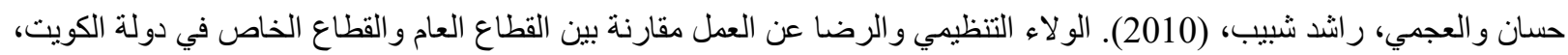
مجلة جامعة الملك عبد العزيز - الاقتصاد والإدارة 13(1). ص 49 -70).

[5] حمدان، دانا لطفي (2008). العلاقة بين الحرية الأكاديمية و الو لا التنظيمي كما براها أعضاء الهيئة التدريسية في الجامعات الفلسطينية، رسالة ماجستير، جامعة النجاح الوطنية، نابلس، فلسطين.

[6] الحمداني، مريم بنت سالم بن حمدان، (2009). الو لاء التنظيمي لأعضاء الهيئة التدريسية في الجامعات الخاصة بسلطنة عمان. (رسالة ماجنتير غير منشورة). جامعة مؤتة. سلطنة عمان.

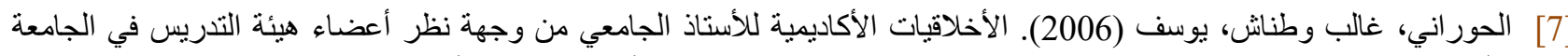
الأردنية، مجلة دراسات العلوم التربوية، المجلد 34، العدد 2007، 2 الجامعة الأردنية، عمان الأردن.

[8] الخشالي، شاكر جاد الله(2003). أثر الأنماط القيادية لرؤساء الأقسام العلمية على الالتز ام التتظيمي لأعضاء هيئة التدريس في الجامعات

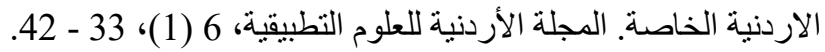

[9] الدجاني، ياسمين(2018). درجة ممارسة القيادة الأخلاقية لاى مديري المدارس الثانوية الخاصة في محافظة العاصمة عمان و علاقتها

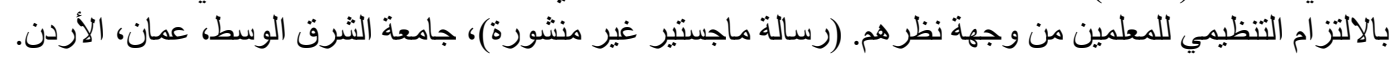

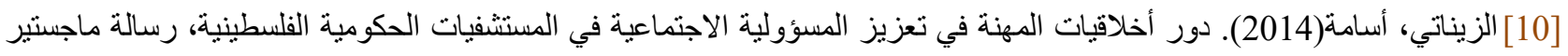
غير منشورة، أكاديمية الإدارة و السياسة للار اسات العليا بالمشاركة مع جامعة الأقصى، جامعة الأقصى، فلسطين. [11] سباعي، محمد عبد الفتاح، (2012). الأخلاقيات في الإدارة، دار و ائل للنشر، ط1، عمان. 


$$
\text { [12] السكارنة، بلال (2016). أخلاقيات المهنة، دار المسيرة للنشر و التوزيع، ط1، عمان، الأردن. }
$$

[13] الثريفي، عباس و التتح، منال. (2011). درجة ممارسة مديري المدارس الثانوية الخاصة بإمارة الثنارقة للقيادة الأخلاقية و علاقتها بدرجة

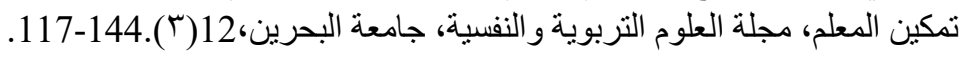

[14] عابدين، محمد وشعيبات، محمد وحلبية، بنان(2012). درجة ممارسة المديرين القيادة الأخلاقية كما يقدر ها معلمو المدارس الحكومة في

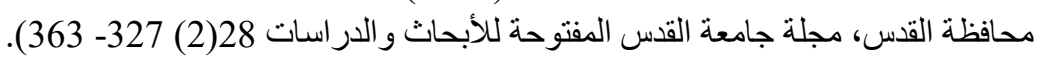

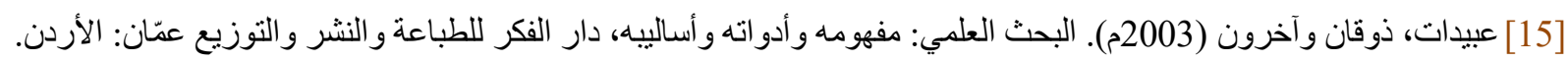

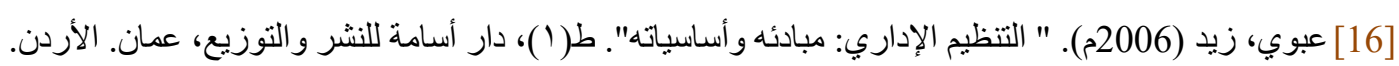

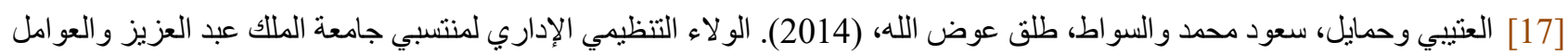

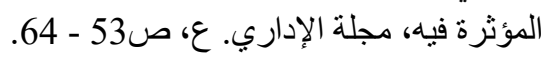

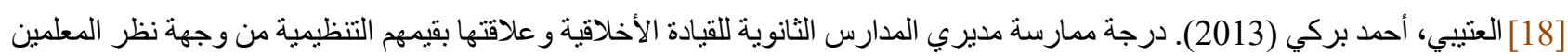

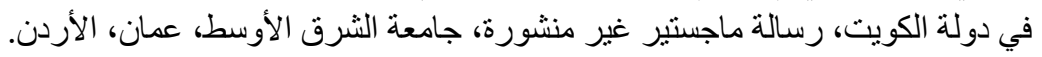

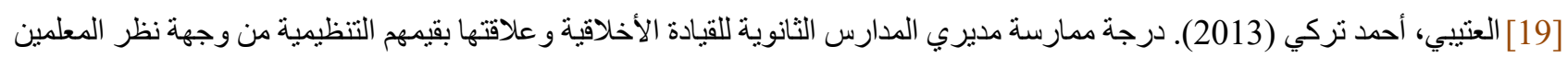
في دولة الكويت. (رسالة ماجستير غير منشورة)، جامعة الثرق الثمارئ الأوسط، عَمان.

[20] العتيبي، سعود (1997). مطلق، السواط: "الو لاء التتظيمي لمنسوبي جامعة الملك عبد الله و العوامل المؤثرة عليه، مج 19، ع ع 70.

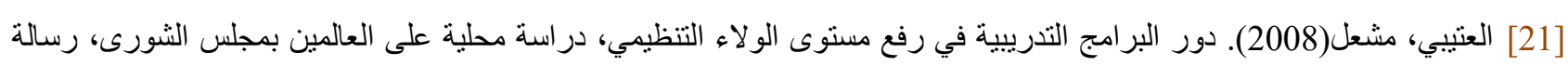
ماجستير، الرياض، جامعلة جامعة نايف للعلوم الأمنية.

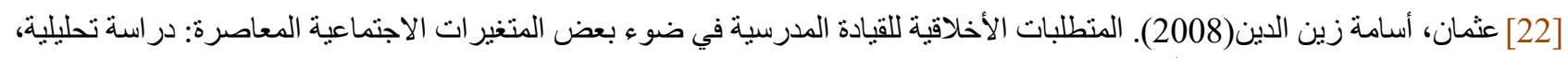

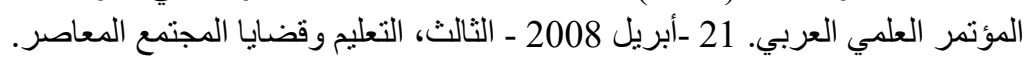

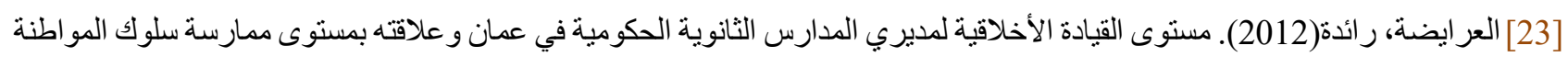

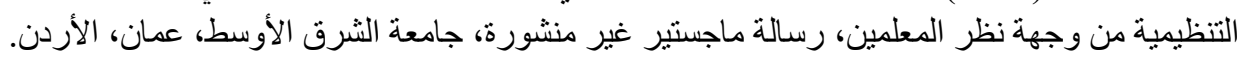

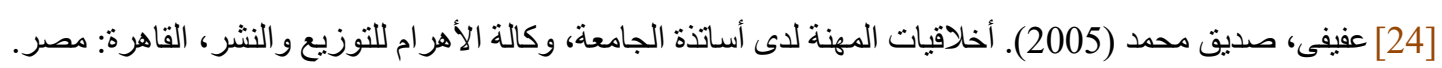

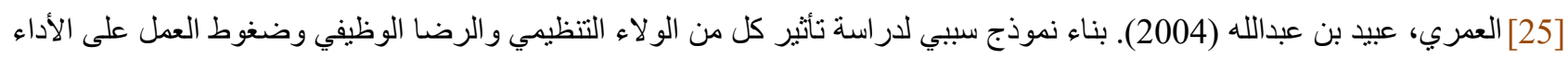

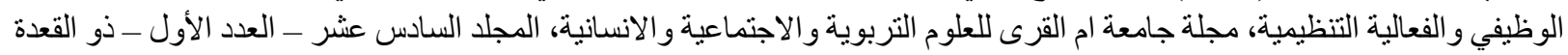
1424 هـ - يناير 2004 م.

[26] المخلافي، محمد سرحان، (2001). أهمية الو لاء التنظيمي و الولاء التتظيمي المهني لدى أعضاء هيئة التدريس في جامعة صنعاءـ كلية

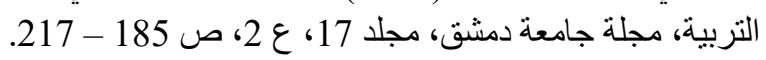

[27] المغربي، عبد الحميد(2007). المهارات السلوكية والتنظيمية لتنمية الموارد البشرية، المنصورة المكتبة العصرية للنشر و التوزيع. [28] الهندي، محمد فضل(2013). درجة ممارسة مدير المدارس الثانوية بمحافظات غزة للقيادة الأخلاقية وعلاقتها بدرجة تمكين معلميهم، رسالة ماجستير ، الجامعة الإسلامية، غزة، فلسطين.

[29] Karakose, T. (2007). High School Teachers Perceptions Reading Principals Ethical Leadership in Turkey. Asia Pacific Education Review, 8 (3), 463-478.

[30] Bowers, T. (2009). Connection Between Ethical Leadership Behavior \& Collective Efficacy Levels as Perceived by Teacher. PhD. USA, Ashland University, Colleague Education.

[31]Ruiz, p; \& Martines, R. (2011). Improving The Leader Follower Relationship: Top Manager or Supervisor?. Journal of Buisness Ethics. Vol. 99. No. 4. PP587-608.

[32] Al- Kahtani, M.A. (2005). An Assessment of Organizational Commitment Imn the Institute of Public Administrative In the Lingdom of Saudi Arabia, The effect of personal demographics and job- related factors on factors on faculty commitment. DAL- B65/07.P.3754.Jan.2005.AAT3140906.

[33] Milyani, H.. (2011). Leadership Ethics. Retried on 15/11/2018 from http: // www. Kauedu.sa/. 


\title{
RESEARCH ARTICLE
}

\section{THE DEGREE OF PRACTICE OF ETHICAL LEADERSHIP BY ACADEMIC LEADERS AT THE UNIVERSITY OF ADEN AND ITS RELATIONSHIP TO ORGANIZATIONAL LOYALTY}

\author{
Ali Muhammad Qasim Obaid Al-Qahtan ${ }^{1, *}$, Nawal Gawad Salem Mohammed Humaydi ${ }^{1}$ \\ ${ }^{l}$ Dept. of Asset management and educational, Faculty of Education - Aden, University of Aden, Yemen
}

*Corresponding author: Ali Muhammad Al-Qahtan; E-mail: ali-khtany@ hotmail.com

Received: 02 September 2021 / Accepted 02 October 2021 / Published online: 31 December 2021

\section{Abstract}

The study aimed to address two of the most important phenomena of organizational behavior, namely, ethical leadership and job loyalty. (Scientific title - years of experience) on the relationship of moral leadership and organizational loyalty of academic leaders at the University of Aden, and knowledge of the differences between the answers of the study community members, with regard to moral leadership and organizational loyalty due to the scientific title, years of experience).

The researchers prepared the questionnaire in its final form and contains (50) paragraphs divided into two axes after presenting it to a group of arbitrators, and after ensuring the validity and stability of the tool, the researcher applied this tool, and (119) copies of the questionnaire were distributed to all academic leaders at the University of Aden (Distributed to the office of the Presidency of the University of Aden and its affiliated colleges and educational centers), the researchers used the descriptive analytical survey method and statistical treatments, and the SPSS statistical program was used to analyze data and information related to the axes of the study and use the appropriate statistical means in processing it and drawing conclusions.

The study showed a set of results, the most important of which are:

1. The degree of moral leadership practice among academic leaders at the University of Aden as (medium) through the level of the general assessment of the axis, which had a general arithmetic mean of (3.22), that is, with a percentage weight of $(64.47 \%)$, and a standard deviation of $(0.852)$.

2. The level of organizational loyalty of academic leaders at the University of Aden at an average level, through the level of the general assessment of the axis, which reached a general arithmetic mean (3.33), that is, with a percentage weight $(66.6 \%)$, and a standard deviation of $(0.615)$.

3. There are no statistically significant differences at the level of significance $(\alpha=0.05)$ between the opinions of the study community members about the degree of practice of the academic leaders at the University of Aden for ethical leadership due to the variables (scientific title, years of experience), as the $(F)$ values calculated in the total scale indicate (1.6) as less than the tabulated $F$ value (2.758).

4. There are no statistically significant differences at the significance level $(\alpha=0.05)$ between the opinions of the study community members about the level of organizational loyalty of the academic leaders at the University of Aden due to the variables (scientific title, years of experience), as the (F) values calculated in the overall scale indicate (0.16). as less than the tabular value (F) (2.758).

5. There is a positive, statistically significant relationship at the significance level $(0.05)$ between the degree of ethical leadership practiced by academic leaders at the University of Aden and their level of organizational loyalty.

Keywords: Job satisfaction, Organizational commitment.

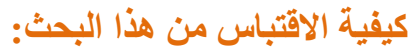

القحطاني، ع. م. ق. ع.، و حميدي، ن. ج. س. م. (2021). درجة ممـارســـة القيادات الأكـاديمية في جامعة عدن للقيادة الأخلاقية و علاقتها

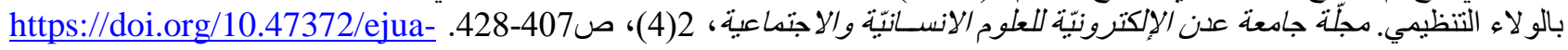
hs.2021.4.129

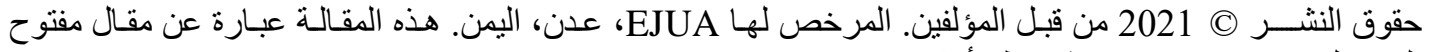

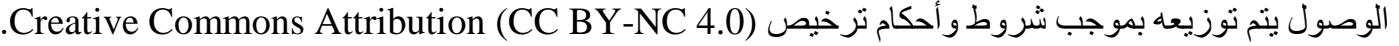

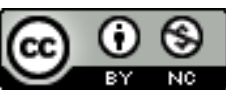

